\title{
Consequences of Elevated Luteinizing Hormone on Diverse Physiological Systems: Use of the LH $\beta$ CTP Transgenic Mouse as a Model of Ovarian Hyperstimulation- induced Pathophysiology
}

\author{
Rachel J. Mann, Ruth A. Keri, and John H. Nilson \\ Department of Pharmacology, Case Western Reserve University School of Medicine, \\ Cleveland, Ohio 44106
}

\begin{abstract}
Chronically elevated luteinizing hormone (LH) induces significant pathology in the LH $\beta$ CTP transgenic mouse model, which uses the bovine gonadotropin alpha $(\alpha)$-subunit promoter to direct transgene expression specifically to gonadotropes in the anterior pituitary. Previously, it was shown that female LH $\beta$ CTP mice are infertile due to anovulation, develop granulosa cell tumors, and undergo precocious puberty from elevated LH and steroid hormones that fail to completely repress the $\alpha$-subunit promoter. This chapter will discuss recent studies that further elucidate the impact of chronically elevated LH on diverse physiological systems. Granulosa cell tumors induced by elevated LH are strain dependent and prevented when transgenics are treated with human chorionic gonadotropin (hCG) surges. A granulosa cell tumor-associated transcriptome is generated, revealing several possible gene candidates for ovarian granulosa cell tumorigenesis. Primordial follicles in LH $\beta C T P$ transgenics become depleted and oocytes exhibit increased rates of meiotic segregation defects, although meiotic competency is acquired normally. Anovulation can be rescued in transgenics by superovulation, though pregnancy fails at midgestation due to maternal factors. Uterine receptivity defects prevent implantation of normal embryos following induction of pseuodpregnancy. Transgenics develop Cushing-like adrenocortical hyperfunction with increased corticosterone production following induction of adrenal $\mathrm{LH}$ receptor expression. Elevated $\mathrm{LH}$ acts as a tumor promoter in the gonads and the adrenal gland, when expressed in conjunction with the inhibin- $\alpha$ SV40 transgene. Finally, chronic elevated LH promotes mammary tumorigenesis. The understanding of multiple clinical pathologies - including ovarian cancer, perimenopausal reproductive aging, premature ovarian failure, polycystic ovarian syndrome, Cushing's syndrome, and breast cancer - may be enhanced through further study of this useful transgenic mouse model.
\end{abstract}

\section{Introduction}

\section{A. PHYSIOLOGICAL ROLE OF LUTEINIZING HORMONE AND THE HYPOTHALAMIC-PITUITARY-GONADAL AXIS}

Luteinizing hormone ( $\mathrm{LH}$ ) is a member of the glycoprotein hormone family, which includes follicle-stimulating hormone (FSH), thyroid-stimulating hormone 
(TSH), and chorionic gonadotropin (CG). These hormones are heterodimers composed of a common $\alpha$ subunit and a unique $\beta$ subunit, which confers hormone specificity (Bousfield et al., 1994). LH is involved primarily in gametogenesis and steroid hormone production in both males and females.

To fully understand the function of LH physiologically, one must understand the context in which it exists. This context includes where it comes from, what drives its production, and what regulates its repression. The major system that controls reproductive physiology in mammals is the hypothalamic-pituitarygonadal (HPG) axis. Gonadotropin-releasing hormone $(\mathrm{GnRH})$, a decapeptide, is secreted in a pulsatile fashion from neurons located in the hypothalamus into the hypothalamic-hypophyseal portal system (Page, 1994). It then exerts its effect through GnRH receptors located on the surface of gonadotrope cells in the anterior pituitary. The seven transmembrane GnRH receptor is a G proteincoupled receptor that stimulates multiple signaling pathways, including modulation of intracellular calcium concentrations and activation of protein kinase $\mathrm{C}$ and other protein kinases (e.g., mitogen-activating protein kinase, MAPK) (Kraus et al., 2001). To what extent these paths cross-talk, or differentially regulate $\mathrm{LH} \beta$ subunit versus the $\alpha$ gonadotropin subunit, is still under investigation (Gajewska and Kochman, 2001). GnRH signaling stimulates both the synthesis and secretion of the gonadotropins LH and FSH from the anterior pituitary.

LH exerts its effect by binding the G protein-coupled LH receptor, initiating signaling primarily through the second messenger, cyclic AMP (cAMP) (Ascoli et al., 2002). In females, LH stimulates ovarian thecal cell production of androstenedione, which diffuses to granulosa cells and undergoes conversion to estrogen by aromatase. FSH controls aromatase activity and also induces the appearance of LH receptors in the granulosa cells of preovulatory follicles, further augmenting estrogen production (Mathews et al., 1987). During the preovulatory surge, LH binds to LH receptors on granulosa cells, stimulating meiotic maturation of the oocyte and release of the oocyte from the follicle. Thus, granulosa cells with both FSH and LH receptors are capable of responding to $\mathrm{LH}$ directly, causing luteinization and release of progesterone (Gore-Langton and Armstrong, 1994). These steroids exert regulatory feedback onto the HPG axis by acting on the hypothalamus and gonadotrope cells, primarily in a negative (repressive) manner (Haisenleder et al., 1994). In males, the role of LH in spermatogenesis via stimulation of androgen production has been well established. Activation of LH receptors on testicular Leydig cells stimulates cAMP release, inducing synthesis of testosterone from cholesterol. In adults, LHstimulated testosterone is the primary determinant of spermatogenesis (Sharpe, 1994). Due to the LH $\beta$ CTP sexually dimorphic phenotype, the remainder of this review will focus primarily on the impact of LH hypersecretion in females. 
A highly regulated system has evolved to ensure that $\mathrm{LH}$ is produced at appropriate concentrations, which, in females, change with time in a cyclic nature. Abnormalities leading to over- or underactivation of the HPG axis have extreme consequences on reproductive health (de Roux and Milgrom, 2001). Too little LH results in underdevelopment of the gonads and subsequent decline (or cessation) of gametogenesis. Too much LH causes precocious puberty and excessive steroid hormone production, which can lead to cell immortalization and tumorigenesis. In humans, inappropriate $\mathrm{LH}$ regulation can result in inability to produce a genetically related family, a hardship that is not only physiologically difficult to overcome but also potentially psychologically debilitating. Thus, it is important that we understand the physiologic role of LH and its ability to induce reproductive pathology upon dysregulation.

\section{B. GENERATING LH HYPERSECRETION IN LH $\beta$ CTP TRANSGENIC MICE}

Many approaches can be taken to generate mice with elevated serum levels of LH. However, most of these methods rely on pharmacological means to elevate LH to nonphysiological levels. In addition, it is difficult to devise protocols for chronic administration of exogenous LH that mimic endogenous LH pulse patterns. By using a transgenic approach, our laboratory not only achieved a physiological means of elevating LH but also limited its synthesis and secretion strictly to gonadotrope cells in the anterior pituitary. This approach leaves intact the HPG axis and permits studies that depend on the responsiveness of this axis. Studying the impact of chronically elevated LH in the whole animal permits a physiological method of disease modeling in multiple, diverse systems, as described in this review.

The LH $\beta$ CTP transgenic mouse was generated by designing a transgene (depicted in Figure 1) that incorporates the C-terminal peptide (CTP) of the hCG $\beta$ subunit fused to the C-terminus of the bovine $\mathrm{LH} \beta$ cDNA and its first intron. The 87-bp CTP fragment extends the half-life of the resulting LH $\beta$ CTP fusion product by 2- to 3-fold (Risma et al., 1995). An SV40 polyadenylation signal was added at the C-terminus of the transgene. Transgene expression is driven by the 360 -bp $(-315$ to +45$)$ bovine gonadotropin $\alpha$-subunit promoter, which has been previously characterized and targets expression specifically to gonadotrope cells in the anterior pituitary (Kendall et al., 1991; Hamernik et al., 1992). This promoter retains responsiveness to GnRH, estrogens, and androgens in transgenic mice (Keri et al., 1991; Hamernik et al., 1992; Clay et al., 1993).

\section{PHENOTYPE OVERVIEW}

Some aspects of the impact of chronic elevated LH on female LH $\beta$ CTP transgenic mice have been reviewed previously in greater detail (Nilson et al., 


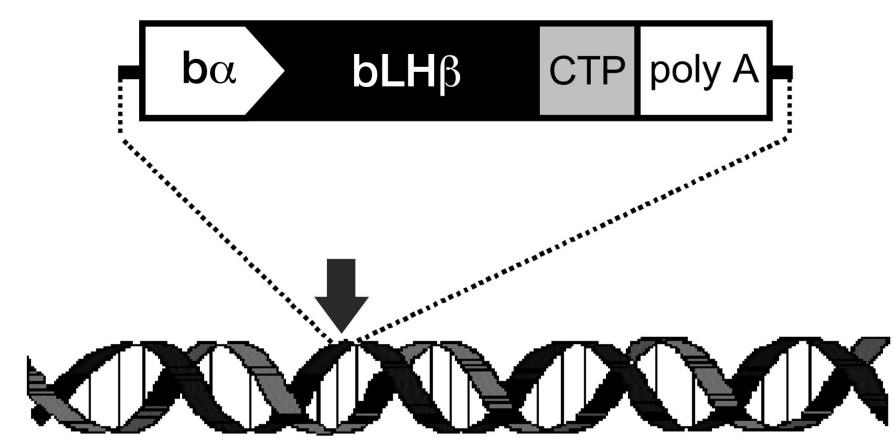

FIG. 1. The LH $\beta$ CTP transgene. The bovine alpha-subunit promoter $(\mathrm{b} \alpha)$ directs expression of the chimeric bovine $\mathrm{LH} \beta$-subunit gene to gonadotropes in the anterior pituitary. The CTP from human chorionic gonadotropin beta (hCG $\beta$ ) fusion confers stability to the $\mathrm{LH}$ in circulation, resulting in an increased half-life.

2000). Originally described in Risma et al. (1995), serum LH is elevated in female transgenics at $39.7 \mathrm{ng} / \mathrm{mL}$ vs. $2.7 \mathrm{ng} / \mathrm{mL}$ in controls. Expression of the transgene led to elevated serum LH levels by at least 2 weeks of age, though serum levels also changed from 2-6 weeks, presumably in response to puberty and the "reawakening" of the HPG axis (Risma et al., 1997). Testosterone in transgenic females is elevated $\approx 5$-fold over control females by 2 weeks of age; estradiol also is elevated by 3 weeks of age by $\approx 2$ - to 5 -fold (Risma et al., 1995,1997).

Despite pathologically elevated levels of steroid hormones, the bovine gonadotropin $\alpha$-subunit promoter driving expression of the LH $\beta$ CTP transgene does not become repressed. In contrast, the endogenous mouse $\mathrm{LH} \beta$-subunit gene becomes completely silent during the transition from the neonatal period to adulthood (Abbud et al., 1999). Interestingly, the endogenous mouse gonadotropin $\alpha$-subunit gene remains active in addition to the transgene. Abbud et al. showed that $\alpha$-subunit promoter activity in the presence of elevated steroid hormones is due to independence from GnRH regulation and, as a result, a lack of responsiveness to estradiol-negative feedback. Since this bovine $\alpha$-subunit promoter previously was shown to be responsive to $\mathrm{GnRH}$ and estradiol in transgenic studies using a chloramphenicol acetyl transferase (CAT) reporter gene (Keri et al., 1991; Hamernik et al., 1992), loss of $\alpha$-subunit promoter responsiveness to GnRH and estradiol must be mediated by the pathological effects of exposure to high levels of LH early in life, possibly through the reprogramming of key signal transduction cascades.

Female LH $\beta$ CTP transgenic mice are infertile due to chronic anovulation, while males appear to have normal fertility. However, male founder transgenics appeared to be slightly subfertile due to breeding delays and had significantly 
smaller testes than controls (Risma et al., 1995). Transgenic females enter puberty precociously at 21 days of age vs. 30 days in controls (Risma et al., 1997). By 3 weeks of age, transgenic females have accelerated folliculogenesis and multifollicular ovaries. By 5-6 weeks of age, transgenic ovaries become significantly enlarged and contain multiple fluid- or blood-filled cysts (Risma et al., 1997). Prolonged luteal life span with elevated serum progesterone is induced in transgenics following hemiovariectomy and mating with vasectomized males. Morphological analyses of ovaries from older animals reveal ovarian granulosa cell tumors or theca-interstitial cell tumors by 4 months of age (Risma et al., 1995).

Transgenic females develop renal abnormalities — including enlarged bladders, dilated ureters, and hydronephrosis - sometimes associated with acute pyelonephritis that can lead to death (Risma et al., 1995). This renal pathology probably is due to exposure to chronically elevated steroids, since hydronephrosis has been observed in rats chronically administered estradiol (Corriere and Murphy, 1968) and is well documented during pregnancy in women (Andriole, 1975). Interestingly, this renal pathology appears to occur most frequently in $\mathrm{CF}-1$ female transgenics but only rarely in [C57BL/6xCF-1] F1 hybrids (Nilson et al., 2000). Thus, female transgenics on C57BL/6 background live longer and go on to develop pituitary hyperplasia by 4 months of age, with pituitary adenoma formation by 10-12 months of age (Nilson et al., 2000).

\section{Pathophysiology Induced by Elevated LH}

\section{A. OVARY PATHOLOGY: MODELING OVARIAN TUMORIGENESIS}

\section{Granulosa Cell Tumors Are Strain Dependent}

Initial studies with LH $\beta$ CTP transgenics were performed on mice with a combined genetic background of CF-1, C57BL/6, and SJL. These mice developed granulosa cell tumors on an occasional basis. However, when the transgene was bred over multiple generations into a pure CF-1 background, the tumor phenotype became $100 \%$ penetrant by 5 months of age. The dependency of tumor formation on genetic background suggested that additional modifiers existed that could act in conjunction with elevated LH to cause or prevent the formation of granulosa cell tumors. In Keri et al., this dependency was investigated. Figure 2 shows the granulosa cell tumor that develops when the transgene is on an undiluted CF-1 background. Transgenic F1 hybrid strains - generated by breeding the CF-1 transgenic mice to CD-1, C57BL/6, or SJL - failed to form granulosa cell tumors. Instead, they uniformly developed cystic ovaries with an extensively luteinized phenotype, reminiscent of a luteoma of pregnancy observed in women (Piana et al., 1999). Therefore, apparent dependence of 


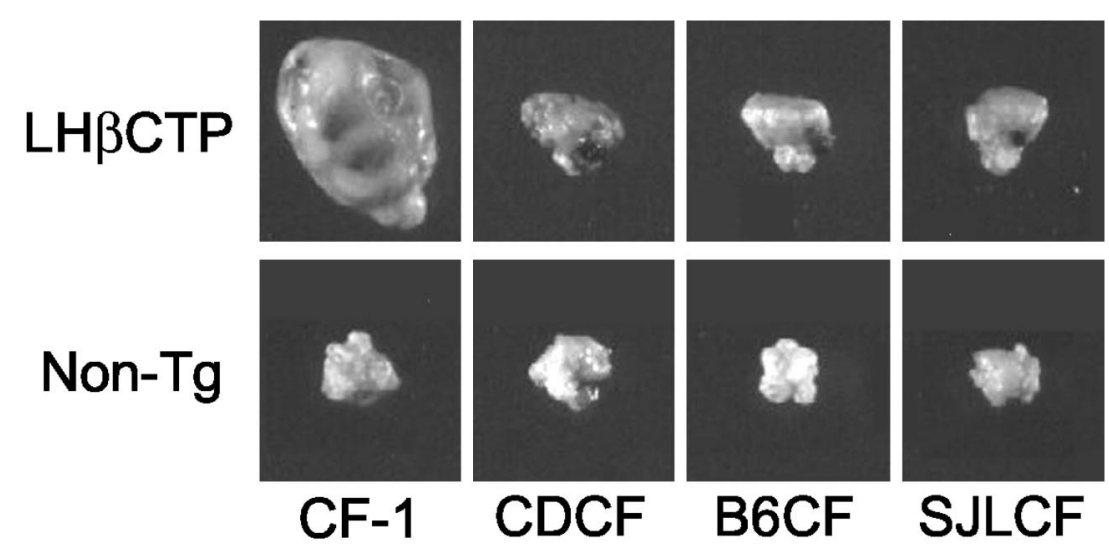

FIG. 2. Granulosa cell tumor induction in response to chronically elevated LH depends on genetic background. Representative ovaries from transgenic (upper panel, LH $\beta \mathrm{CTP}$ ) or nontransgenic (lower panel, Non-Tg) mice from either the CF-1 parental strain or F1 hybrid strains. CDCF =

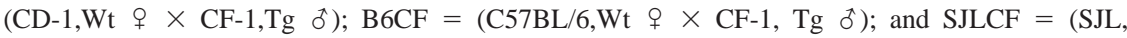
$\mathrm{Wt}+{ }^{\circ} \times \mathrm{CF}-1, \mathrm{Tg} \delta$ ). [Reprinted with permission from Keri RA, Lozada KL, Abdul-Karim FW, Nadeau JH, Nilson, JH 2000 Luteinizing hormone induction of ovarian tumors: oligogenic differences between mouse strains dictates tumor disposition. Proc Natl Acad Sci USA 97:383-387. Copyright (2000) National Academy of Sciences, U.S.A.]

granulosa cell tumor formation on a specific genetic profile may explain the rarity of these tumors in women (Wynder et al., 1969).

At 5 months of age, all F1 hybrid transgenics had elevated $\mathrm{LH}$, even relative to transgenics on the CF-1 background. An altered hormonal profile, ovarian cysts, and precocious puberty are phenotypes induced by the transgene that are independent of strain background. The fact that the granulosa cell tumor phenotype was lost after only one generation of breeding suggests that at least one gene with recessive effects must be involved in the differential ovarian response to elevated LH (Keri et al., 2000).

To estimate the number of recessive genes involved in granulosa cell tumor strain dependency, backcrosses between the C57BL/6xCF-1 F1 transgenic hybrids ( $\hat{O}$ ) and CF-1 nontransgenics ( 9 ) were performed. Of the 138 transgenic females generated from this study, 19 harbored at least one granulosa cell tumor. The fit between the predicted and observed (13.8\%) frequency of tumor appearance supports a three-gene model (Keri et al., 2000). The expected (predicted) frequency of tumor formation for two-, three-, and four-gene models are, respectively, $25 \%, 12.5 \%$, and $6.25 \%$ (predicting $34.5,17.3$, and 8.6 tumors out of 138 evaluated). Subsequent to this publication, more transgenic females have been evaluated, altering the final observed frequency to 30/295 (10.2\%), further 
supporting that three unlinked, recessive genes may discriminate tumor susceptibility in response to elevated LH (R.A. Keri, personal communication).

Ongoing studies to determine the identity of the genes required for granulosa cell tumors are being performed using microsatellite markers and bulk segregant analysis to identify contributing loci. Recent preliminary data indicate phenotype linkage to mouse chromosomes 10 and 11 (R.A. Keri, personal communication).

\section{LH Surges Prevent Granulosa Cell Tumor Formation}

While granulosa cell tumors comprise only $10 \%$ of ovarian tumors, they exhibit the potential for malignancy and recurrence, making them clinically significant (Wynder et al., 1969, Fontanelli et al., 1998; Lee et al., 1999). Efforts to identify the molecular mechanisms leading to development of these tumors are important, as they may reveal possible new therapeutic targets.

Clinical studies have implicated elevated gonadotropins levels in tumorigenesis. The strongest correlative evidence comes from postmenopausal women, who represent the largest cohort of patients with granulosa cell tumors (Amsterdam and Selvaraj, 1997).

Studies using other types of transgenic mice support this view as well. Mice deficient in inhibin $\alpha$ develop granulosa cell tumors at an early age (Matzuk et al., 1992). The lack of inhibin $\alpha$ leads to an increase in LH, FSH, and estrogens (Kumar et al., 1999). When these animals also are made genetically deficient for $\mathrm{GnRH}$ (hpg/hpg), tumors fail to form, further underscoring the importance of LH and FSH (Kumar et al., 1996). In contrast, mice deficient in FSH and inhibin continue to develop tumors, although with increased latency and decreased penetrance (Kumar et al., 1999). These data suggest that elevated LH, independent of FSH, can induce granulosa cell tumor formation when mice also are deficient for inhibin $\alpha$, while FSH may accelerate this process (Owens et al., 2002).

In Owens et al. (2002), subtractive gene expression profiling was employed, comparing normal ovaries, LH $\beta$ CTP (CF-1) granulosa cell tumors, and LH $\beta$ CTP (F1 hybrids) luteomas. This subtractive method (diagrammed in Figure 3) was employed to evaluate the differential gene expression profile that distinguishes a granulosa cell tumor from a normal or luteoma-bearing ovary. Equal amounts of total RNA were pooled from at least four mice for each experimental group, to minimize changes due to interindividual variation. Global changes in gene expression profiles were assessed with Affymetrix Mu11K oligodeoxynucleotide microarrays containing approximately 11,000 genes and expressed sequence tags (ESTs). Samples were normalized to glyceraldehyde-3-phosphate dehydrogenase (GAPDH) and analyzed using self-organizing maps (SOMs) to reveal informative patterns of gene expression (Tamayo et al., 1999). The data were filtered using Affymetrix parameters to exhibit changes that were at least 3-fold, since 
A.

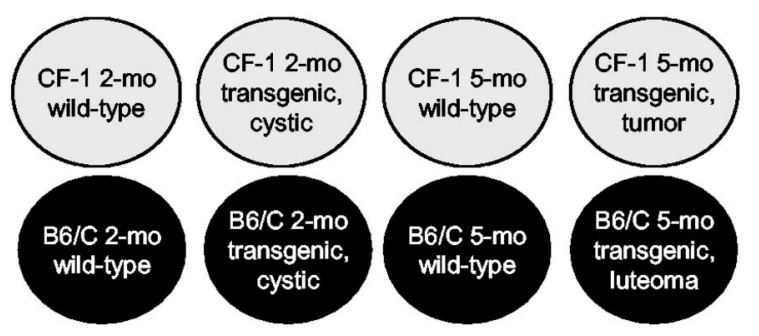

Experimental Groups for Expression Profiling

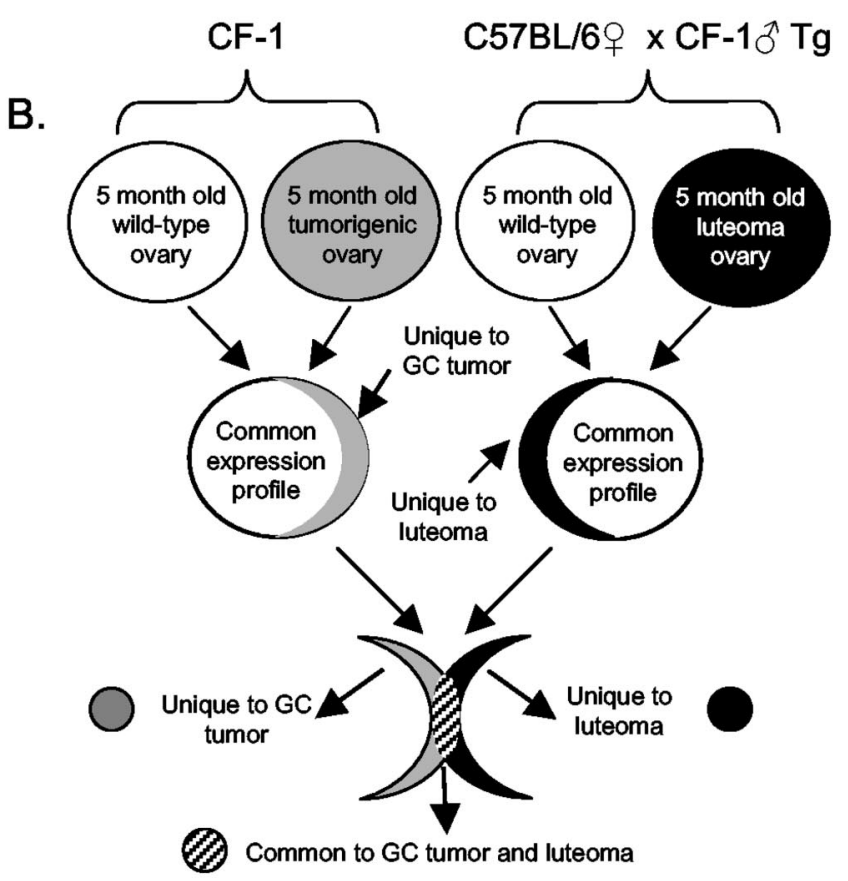

FIG. 3. Subtractive gene-expression profiling compares normal ovaries, LH $\beta$ CTP (CF-1) granulosa cell tumors, and LH $\beta$ CTP (F1 hybrids) luteomas. (A) Eight experimental groups are represented by the circles; $\mathrm{B} 6 / \mathrm{C}=\left(\mathrm{C} 57 \mathrm{BL} / 6, \mathrm{Wt}+{ }^{\circ} \times \mathrm{CF}-1, \mathrm{Tg} \sigma\right)$. (B) The expression-profiling technique is diagrammed with four of the eight experimental groups for simplicity. The small percentage of genes from each comparison group is overlapped, identifying genes associated only with the formation of a granulosa cell tumor. [Reprinted with permission from Owens GE, Keri RA, Nilson JH 2002 Ovulatory surges of hCG prevent hormone-induced granulosa cell tumor formation leading to the identification of tumor-associated changes in the transcriptome. Mol Endocrinol 16:1230-1242. Copyright The Endocrine Society.] 
these are highly reproducible in replicate samples (Cho et al., 1998). Clusters were generated of 47 genes whose expression dramatically decreased and 75 whose expression increased significantly.

To identify consistent patterns in the tumor-associated transcriptome, analysis of RNA from tumors and luteomas was repeated on a new sample set containing three ovaries in each group. This further limited the cluster of genes with dramatic expression changes to 26 reduced and 46 increased. These genes, listed in Tables I and II, may represent common expression alterations that contribute to granulosa cell tumor formation in LH $\beta$ CTP mice (Owens et al., 2002).

Many of the genes identified have been associated previously with ovarian tumors (e.g., c-fos, N-myc, platelet-derived growth factor (PDGF)-A, inhibin $\beta$ A and $\beta \mathrm{B}$ ), further implicating them as contributors to the tumor phenotype (Versnel et al., 1994; Gercel-Taylor and Taylor, 1996; Luthra and Chapekar, 1998; deKretser et al., 2000). Further verification of a subset of the identified cluster genes was performed by semiquantitative reverse transcription-polymerase chain reaction (RT-PCR) on granulosa cell tumors and luteomas obtained from individual animals (as opposed to the RNA pooling done previously). Expression differences in LH-R, steroidogenic acute regulator protein (StAR), inhibin $\beta \mathrm{B}$, and Wnt-4 observed between luteomas and granulosa cell tumors through microarray analyses were recapitulated.

Owens et al. further evaluated the role of elevated LH in granulosa cell tumor development by determining whether the lack of ovulatory surges of $\mathrm{LH}$ in genetically predisposed $\mathrm{LH} \beta \mathrm{CTP}(\mathrm{CF}-1)$ mice might contribute to the granulosa cell tumor phenotype. LH $\beta$ CTP CF-1 mice were treated with ovulatory doses of hCG every fourth day for 5 months, beginning at 2 weeks of age. Transgenic female littermates in control groups received saline injections. All transgenic animals $(n=4)$ receiving $h C G$ injections failed to develop granulosa cell tumors while, as expected, all littermate controls $(\mathrm{n}=3)$ receiving saline injections developed tumors by 5 months of age (Owens et al., 2002). Ovaries from all four hCG-treated animals developed luteomas, a histological phenotype indistinguishable from those seen in F1 hybrid transgenics (C57BL/6xCF-1). This result indicates that long-term restoration of ovulatory surges of hCG is capable of antagonizing the genetic predisposition for granulosa cell tumor formation in CF-1 transgenic mice. Interestingly, the ovarian transcriptome of CF-1 transgenic mice treated with hCG closely resembled that of the F1 hybrid transgenics (C57BL/6xCF-1). These results are shown in the right column of Tables I and II.

Figure 4 depicts the finding that chronically elevated LH initiates a molecular pathway that, in conjunction with a genetic predisposition, leads to the development of granulosa cell tumors. However, in the absence of this genetic predisposition, or in the presence of ovulatory-like surges of hCG, chronically 
TABLE I

Gene Expression Decreases Associated with Granulosa Cell Tumors

\begin{tabular}{|c|c|c|c|}
\hline $\begin{array}{l}\text { Accession } \\
\text { number }\end{array}$ & Gene name & $\begin{array}{l}\text { Average-fold decrease } \\
\text { (tumor vs. luteoma) }\end{array}$ & $\begin{array}{l}\text { Reproduced in hCG- } \\
\text { induced luteoma }\end{array}$ \\
\hline AA087277 & Secreted frizzled related protein 4 & 400 & Yes \\
\hline Z27088 & Relaxin precursor & 300 & Yes \\
\hline AA122502 & $\begin{array}{l}\text { NG-CAM related adhesion } \\
\text { molecule precursor }\end{array}$ & 150 & Yes \\
\hline M14757 & Multidrug resistant protein & 100 & No \\
\hline M89797 & Wnt-4 & 100 & Yes \\
\hline W15994 & Laminin B receptor & 49.0 & 1 \\
\hline D17433 & Prostaglandin F receptor & 43.0 & \\
\hline L36062 & StAR & 33.0 & \\
\hline D14636 & PEBP2a1 protein & 32.0 & \\
\hline D32137 & MOPG & 31.0 & $\downarrow$ \\
\hline W41963 & Acetyl-CoA synthetase & 16.0 & No \\
\hline M62766 & HMG-CoA reductase & 14.0 & Yes \\
\hline $\mathrm{Z} 22532$ & Syndecan-1 & 13.0 & No \\
\hline I13593 & Prolactin receptor & 11.5 & Yes \\
\hline D42048 & Squalene epoxidase & 9.5 & No \\
\hline X61940 & $\begin{array}{l}\text { Growth factor-inducible immediate } \\
\text { early gene }\end{array}$ & 9.0 & Yes \\
\hline AA066425 & Tumor-associated antigen & 8.5 & No \\
\hline M81310 & Luteinizing hormone receptor & 8.0 & Yes \\
\hline X56304 & Tenascin & 7.5 & \\
\hline U49507 & Lisch 7 & 7.0 & \\
\hline M28698 & Cytokeratin 19 & 7.0 & $\downarrow$ \\
\hline AA016727 & Farnesyl pyrophosphate synthetase & 7.0 & No \\
\hline I05781 & Cytosolic epoxide hydrolase & 6.0 & Yes \\
\hline M37761 & Calycyclin & 6.0 & \\
\hline M31419 & 204 interferon activatable protein & 5.5 & \\
\hline AA000961 & Hemoglobinase precursor & 3.0 & $\downarrow$ \\
\hline
\end{tabular}

[Reprinted with permission from Owens GE, Keri RA, Nilson JH 2002 Ovulatory surges hCG prevent hormone-induced granulosa cell tumor formation leading to the identification of tumorassociated changes in the transcriptome. Mol Endocrinol 16:1230-1242. Copyright The Endocrine Society.]

elevated levels of $\mathrm{LH}$ result in the formation of a luteoma rather than a granulosa cell tumor. Further molecular clarification of the signaling pathways involved in these two different outcomes may help refine our understanding of human granulosa cell tumors as well as the molecular pathways regulated by LH. 


\section{B. FOLLICLE AND OOCYTE DEVELOPMENT: MODELING PERIMENOPAUSAL REPRODUCTIVE AGING AND PREMATURE OVARIAN FAILURE}

\section{Primordial Follicles Are Depleted in LHßCTP Mice}

In human females, the nonrenewable follicular reserve of dormant primordial follicles becomes depleted with age and usually is exhausted between ages 45 and 55 (Richardson and Nelson, 1990). While depletion occurs gradually throughout the reproductive life span, as primordial follicles are recruited into the growing follicular pool, during the period of perimenopause, the loss of primordial follicles accelerates at a rate twice that seen previously (Richardson et al., 1987). If not for this acceleration, women would remain fertile well into their eighties (Faddy et al., 1992). During perimenopause, women experience transient elevations in the levels of both LH and FSH (Sherman et al., 1976; Marcus et al., 1993). It is thought that this altered endocrine milieu exerts a toxic effect on the primordial follicle pool, accelerating its depletion (Richardson et al., 1987).

Accelerated primordial follicle depletion also is seen in the disorder known as premature ovarian failure (POF). Although of unknown origin, POF clearly is associated with early and accelerated follicle atresia (Rebar, 1982; Cohen and Speroff, 1991). POF is characterized by primary or secondary amenorrhea, with elevated levels of serum gonadotropins and early menopause (Bione et al., 1998). Women with POF are infertile due to anovulation, experience depletion of their follicular reserve, and show hormonal profiles similar to older women who are postmenopausal (Russell, 1997).

In Flaws et al. (1997), ovaries from LH $\beta$ CTP mice were evaluated for follicular depletion. By scoring serial sections of ovaries obtained from transgenics and control littermates, a 45\% decline in primordial follicles was observed in transgenics by 5 weeks of age. By 3 months, ovaries from transgenic mice contained 68\% fewer primordial follicles, when compared to controls (Figure 5). As the primordial follicle pool becomes depleted, primary follicle numbers begin to decline as well. By 3 months, primary follicles are $45 \%$ depleted in transgenics vs. controls (Flaws et al., 1997). These data suggest that elevated LH leads to depletion of the primordial and primary follicle pool and thus alters the timing of reproductive senescence. Further evaluation of the molecular mechanism of this depletion may increase our understanding of primordial pool depletion observed during perimenopause and POF.

\section{Oocyte Meiotic Competency Is Not Altered}

The altered hormonal milieu and associated ovarian pathology in transgenic females occur around the time of precocious puberty (21 days), which is also the 
TABLE II

Gene Expression Increases Associated with Granulosa Cell Tumors

\begin{tabular}{|c|c|c|c|}
\hline $\begin{array}{l}\text { Accession } \\
\text { number }\end{array}$ & Gene name & $\begin{array}{l}\text { Average-fold } \\
\text { decrease (tumor } \\
\text { vs. luteoma) }\end{array}$ & $\begin{array}{l}\text { Reproduced in } \\
\text { hCG-induced } \\
\text { luteoma }\end{array}$ \\
\hline X13586 & 2,3-bisphosphoglycerate mutase & 130 & Yes \\
\hline U81603 & Eya2 homolog & 40.0 & \\
\hline W35058 & Frizzled 1 & 39.0 & \\
\hline U85610 & Indian hedgehog protein & 27.0 & \\
\hline AB004048 & Neuronatin & 26.0 & \\
\hline J04946 & Angiotensin converting enzyme & 22.0 & \\
\hline AA111277 & Visinin-like protein & 22.0 & \\
\hline U37459 & $\begin{array}{l}\text { Glia-derived neurotrophic growth factor } \\
\text { (GDNF) }\end{array}$ & 21.0 & $\downarrow$ \\
\hline M69069 & MHC class I mRNA & 21.0 & No \\
\hline X68837 & Secretogranin II & 17.0 & Yes \\
\hline M29464 & Platelet-derived growth factor A-chain & 14.0 & \\
\hline X69620 & Inhibin $\beta$-B subunit & 12.0 & \\
\hline AA 105452 & Glia-derived nexin precursor & 10.0 & \\
\hline M15525 & Laminin B1 & 10.0 & \\
\hline X03919 & $\mathrm{N}$-myc & 9.5 & \\
\hline X69619 & Inhibin $\beta$-A subunit & 9.0 & \\
\hline I056439 & IGFBP-2 & 9.0 & \\
\hline M18194 & Fibronectin & 9.0 & \\
\hline AA097626 & Pol polyprotein & 9.0 & \\
\hline X94322 & Melanoma-inhibitory-activity protein & 8.5 & \\
\hline V00727 & c-fos oncogene & 8.0 & \\
\hline X13945 & L-myc & 8.0 & \\
\hline M70642 & FiSP-12 & 8.0 & $Y$ \\
\hline U17961 & p62 mRNA & 7.0 & No \\
\hline AA035915 & Ras-like protein TC21 & 6.5 & Yes \\
\hline U79766 & Ajuba & 6.0 & No \\
\hline AF004326 & Angiopoietin-2 & 6.0 & Yes \\
\hline W48402 & SIR2 & 5.5 & \\
\hline X89627 & 17-beta-hydroxysteroid & 5.5 & \\
\hline AA064226 & $\begin{array}{l}\text { dehydrogenase } \\
\text { RAB-11B }\end{array}$ & 5.5 & \\
\hline M31131 & N-cadherin & 5.0 & \\
\hline X70853 & Fibulin C & 5.0 & \\
\hline W82053 & $\mathrm{EF}-2$ & 5.0 & \\
\hline W41733 & Protein kinase $\mathrm{C}$ substrate & 5.0 & \\
\hline X75285 & Fibulin 2 & 5.0 & \\
\hline X70854 & Fibulin D & 4.0 & \\
\hline Z28532 & Follistatin & 4.0 & $\downarrow$ \\
\hline
\end{tabular}


TABLE II

(continued)

\begin{tabular}{llcc}
\hline $\begin{array}{l}\text { Accession } \\
\text { number }\end{array}$ & Gene name & $\begin{array}{l}\text { Average-fold } \\
\text { decrease (tumor } \\
\text { vs. luteoma) }\end{array}$ & $\begin{array}{l}\text { Reproduced in } \\
\text { hCG-induced } \\
\text { luteoma }\end{array}$ \\
\hline AA063914 & Tubulin alpha chain & 3.5 & $\downarrow$ \\
L04538 & Amyloid precursor-like protein & 3.5 & No \\
AF119416 & GM3 synthase & 3.5 & Yes \\
U79748 & DPC4 & 3.5 & $\downarrow$ \\
X70853 & Fibulin C & 3.0 & $\downarrow$ \\
W13162 & CDK4 & 3.0 & $\downarrow$ \\
W43968 & Myosin heavy chain 1B & 3.0 & $\downarrow$ \\
W81863 & Extensin precursor & 3.0 & \\
Z22784 & Troponin 1 & 3.0 &
\end{tabular}

[Reprinted with permission from Owens GE, Keri RA, Nilson JH 2002 Ovulatory surges hCG prevent hormone-induced granulosa cell tumor formation leading to the identification of tumorassociated changes in the transcriptome. Mol Endocrinol 16:1230-1242. Copyright The Endocrine Society.]

time during which oocyte meiotic competency is acquired. Along with LH, testosterone becomes elevated in transgenics by 2 weeks of age (Risma et al., 1997). Abnormally elevated levels of androgens are thought to induce follicular atresia and oocyte degeneration (Hsueh et al., 1994). Other studies have suggested that elevated androgens can cause premature activation of meiotic prophase I-arrested oocytes (Wasserman et al., 1994). In addition to androgeninduced follicular demise, elevated levels of LH may have a direct detrimental impact on oocyte development (Jacobs and Homburg, 1990). For example, increased LH concentrations during the follicular phase may result in the inappropriate activation of meiotic prophase I-arrested oocytes (Wasserman et al., 1994).

Meiotic competency, or the ability to resume meiosis after release from the ovarian follicle, is indicated by germinal vesicle breakdown (GVBD), followed by polar body (PB) extrusion after overnight culture. No differences could be observed between transgenics or control littermates: at 15 days of age, oocytes arrest at GVBD, while at 21 days, meiotic competency has been acquired and oocytes extrude a polar body, presumably arrested at metaphase of meiosis I (Mann et al., 1999). Thus, despite development within the context of elevated $\mathrm{LH}$, estrogen, and testosterone, and the depletion of primordial follicles, acquisition of meiotic competency in oocytes from transgenics overtly appears to remain unaltered. 


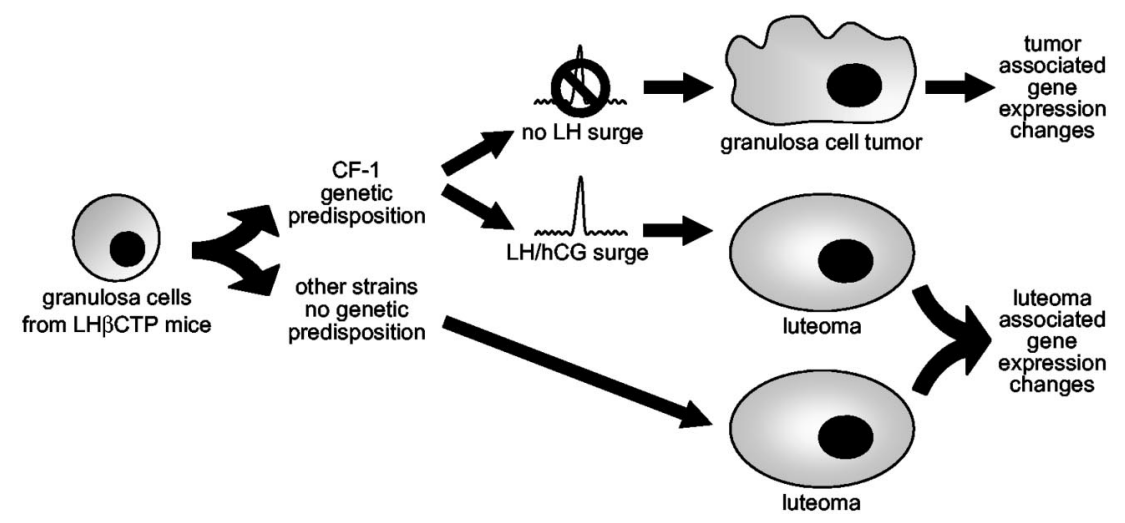

FIG. 4. Unique transcriptomes couple with genetic factors to induce granulosa cell tumors or luteomas. This model illustrates that chronically elevated LH, as well as potential alterations in androgens and other growth factors, initiates one of two basic tumorigenic pathways. The pathway taken depends on genetic predisposition and can be modified by hormonal intervention. [Reprinted with permission from Owens GE, Keri RA, Nilson JH 2002 Ovulatory surges of hCG prevent hormone-induced granulosa cell tumor formation leading to the identification of tumor-associated changes in the transcriptome. Mol Endocrinol 16:1230-1242. Copyright The Endocrine Society.]

\section{Elevated LH Increases the Rate of Oocyte Meiotic Segregation Defects}

While acquisition of meiotic competency occurs normally in transgenics, elevated LH does significantly impact the organization of chromosomes on the meiotic I spindle during oocyte maturation (Hodges et al., 2002). This study suggests that the altered endocrine milieu of $\mathrm{LH} \beta \mathrm{CTP}$ transgenics results in an increase in meiotic nondisjunction, similar to that observed during human reproductive aging.

Errors in chromosome segregation during human meiotic divisions result in the loss of a significant number of conceptions. The high incidence of meiotic errors in humans has a strong correlation to maternal age (Hassold and Chiu, 1985), though the mechanisms underlying these errors remain unclear. Data show that the age-related increase in oocyte meiotic errors is characteristic of all racial groups (Hassold and Chiu, 1985) and that most meiotic errors have their genesis at meiosis I (Hassold and Hunt, 2001). Studies on human trisomies have further elucidated the impact of age on meiotic nondisjunction but have not revealed the molecular mechanisms involved (Hodges et al., 2002). Recently, immunofluorescent studies have suggested that early events in meiosis I may contribute to subsequent nondisjunction (Battaglia et al., 1996; Volarcik et al., 1998).

Congression failure, or the inability of chromosomes to move to the equator of the meiosis I (MI) spindle due to gross aberrations in spindle morphology 


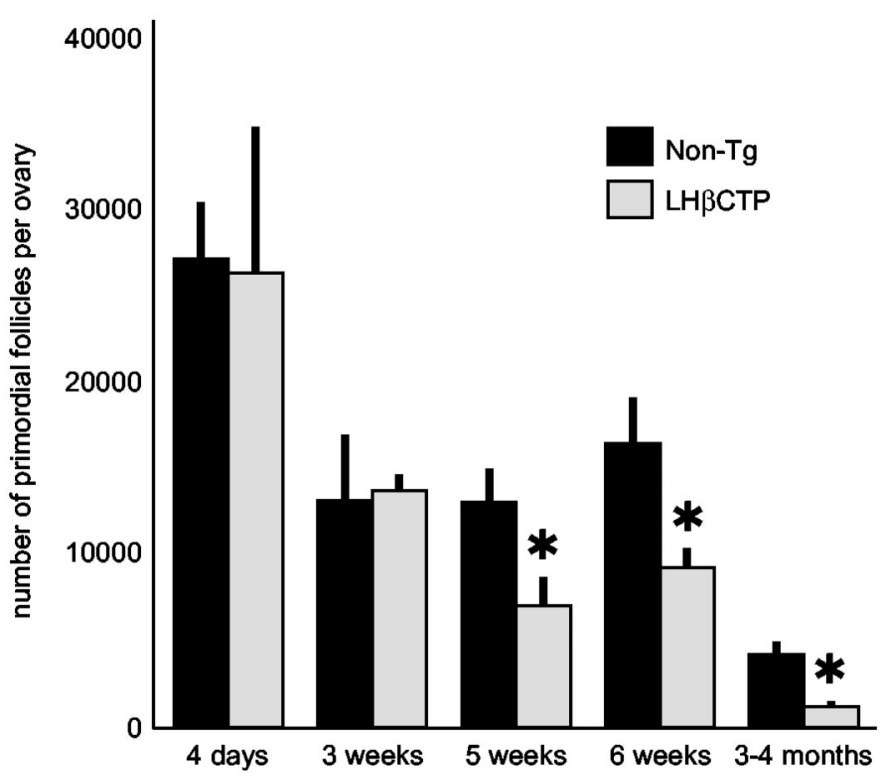

FIG. 5. Chronically elevated LH depletes primordial follicle pools. Ovaries from control (nontransgenic) and transgenic (LH $\beta C T P$ ) mice were collected and sectioned at the ages indicated. Every fifth section was sampled to estimate the number of primordial follicles per ovary. *Significantly different from control. [Reprinted with permission from Flaws JA, Abbud R, Mann RJ, Nilson JH, Hirshfield AN 1997 Chronically elevated luteinizing hormone depletes primordial follicles in the mouse ovary. Biol Reprod 57:1233-1237.]

and/or chromosome alignment, is another age-related phenomenon (Volarcik et al., 1998). Since female meiosis (unlike mitosis or male meiosis) is not subject to chromosomal monitoring checkpoint mechanisms of the metaphase/anaphase transition, this alignment failure may be linked to eventual nondisjunction (LeMaire-Adkins et al., 1997; Woods et al., 1999; Burke, 2000; Shah and Cleveland, 2000).

Because the altered endocrine environment is known to disrupt folliculogenesis in the LH $\beta$ CTP female, Hodges et al. evaluated oocytes from LH $\beta$ CTP transgenics (and other mouse models) for evidence of congression failure and subsequent indications of nondisjunction. On both a heterogeneous background and the C57BL/6 inbred strain, oocytes from the first follicular wave in LH $\beta$ CTP were analyzed for chromosome alignment at metaphase I (6 hours in culture) and metaphase II (16-18 hours in culture). Table III shows the results of these studies (Hodges et al., 2002). A high level of congression failure was observed at both MI (18.2\% vs. $0-1 \%$ in controls) and meiosis II (MII) metaphase (38.6\% vs. $0 \%$ in controls) in LH $\beta$ CTP mice. In addition, meiotically immature oocytes from 
TABLE III

Chromosome Alignment at Metaphase in Oocytes

\begin{tabular}{lcccccc}
\hline & $\begin{array}{l}\text { Hours in } \\
\text { culture }\end{array}$ & $\begin{array}{l}\text { Meiotic } \\
\text { stage }\end{array}$ & $\begin{array}{l}\text { Total cells } \\
\text { scored }\end{array}$ & $\begin{array}{l}\text { Normal MI } \\
\text { alignment }(\%)\end{array}$ & $\begin{array}{l}\text { Congression } \\
\text { failure }(\%)\end{array}$ & $\begin{array}{c}\text { Congression with } \\
\text { outliers }(\%)\end{array}$ \\
\hline $\begin{array}{c}\text { Control } \\
(26-28 \text { day })\end{array}$ & 8 & MI & 147 & $137(93)$ & 0 & $10(7)$ \\
& 10 & MI & 227 & $210(93)$ & $3(1)$ & $14(6)$ \\
& $16-18$ & MII & 59 & $58(98)$ & 0 & $1(2)$ \\
$\begin{array}{c}\text { Partially competent } \\
(18-20 \text { day) }\end{array}$ & 8 & MI & 43 & $35(81)$ & 0 & $8(19)$ \\
& $16-18$ & MI & 42 & $45(98)$ & 0 & $1(2)$ \\
LH $\beta$ CTP & 6 & MI & 88 & $67(76)$ & $16(18)$ & $5(6)$ \\
$(26-28$ day $)$ & & & & & & $7(12)$ \\
\hline
\end{tabular}

[Hodges CA, Ilagan A, Jennings D, Keri K, Nilson J, Hunt PA 2002 Experimental evidence that changes in oocyte growth influence meiotic chromosome segregation. Hum Reprod 17:1171-1180. (C) European Society of Human Reproduction and Endocrinology. Adapted by permission of Oxford University Press/Human Reproduction.]

nontransgenics (partially competent 18- to 20-day-old mice) did not exhibit congression failure. These studies show that congression failure is not a symptom of meiotic immaturity but, rather, a reflection of oocyte growth in an altered environment. It also was observed that the degree of meiotic disturbance appeared to correlate to the extent of ovarian pathology, another indicator of the abnormal endocrine environment.

Both microinjection of kinetochore antibodies into mouse oocytes (Simerly et al., 1990) and immunodepletion of kinetochore-associated motor protein, CENP-E, in Xenopus egg extracts (Wood et al., 1997) produce a congression failure phenotype. Thus, Hodges et al. postulated that the congression failure observed in LH $\beta$ CTP oocytes (and reproductively aged human oocytes) may be due to endocrine affects on production of one or more microtubule motor proteins.

Hodges et al. also asked if congression failure causes an increase in oocyte aneuploidy through nondisjunction and premature sister chromatid segregation (PSCS). Table IV shows that LH $\beta$ CTP-derived oocytes do exhibit a significant increase in total hyperploidy and/or PSCS (18\% vs. 5\% controls). These data, along with data from another congression failure mutant (not shown), support the conclusion that increased frequency of congression failure at MI results in increased impairment of segregation of homologous chromosomes at anaphase I. 
TABLE IV

Chromosome Analysis of Metaphase II-arrested Oocytes

\begin{tabular}{|c|c|c|c|c|c|}
\hline & $\mathrm{n}$ & $\begin{array}{l}\text { Normal } \\
\text { chromosomes } \\
(\%)\end{array}$ & PSCS $(\%)$ & $\begin{array}{l}\text { Hyperploid } \\
(\%)\end{array}$ & $\begin{array}{l}\text { PSCS \& } \\
\text { hyperploid }(\%)\end{array}$ \\
\hline Controls & 44 & $42(95)$ & $2(5)$ & - & - \\
\hline LH $\beta C$ TP & 44 & $36(82)$ & $2(5)$ & $3(7)$ & $3(7)$ \\
\hline
\end{tabular}

[Hodges CA, Ilagan A, Jennings D, Keri K, Nilson J, Hunt PA 2002 Experimental evidence that changes in oocyte growth influence meiotic chromosome segregation. Hum Reprod 17:1171-1180. (C) European Society of Human Reproduction and Endocrinology. Adapted by permission of Oxford University Press/Human Reproduction.]

These results suggest that changes in the endocrine milieu that occur during human reproductive aging and the perimenopausal period may contribute significantly to the age-related increase in oocyte meiotic nondisjunction, possibly due to errors in chromosomal alignment at MI, such as those seen during congression failure.

\section{INFERTILITY: MODELING POLYCYSTIC OVARIAN SYNDROME}

Clinical observations have shown that hypersecretion of LH impairs fertility in women by disrupting ovarian function and maintenance of pregnancy (Regan et al., 1990; Balen et al., 1993; Shoham et al., 1993). Polycystic ovarian syndrome (PCOS) affects up to $10 \%$ of women of reproductive age and is a leading cause of anovulatory infertility (Adams et al., 1986). Women with PCOS typically present with elevated $\mathrm{LH}$ and androgens, chronic anovulation, and polycystic ovaries (Franks, 1995). However, PCOS is an etiologically complex disorder that often is associated with hirsutism, obesity, insulin resistance, and pregnancy complications (Legro et al., 1998). Elucidating the mechanism by which elevated LH induces female reproductive disorders such as PCOS has been difficult due to the complexity of these syndromes. Generating a mouse model that recapitulates many of the features of PCOS would be useful to allow for greater understanding of its treatment and prevention.

Women with elevated LH who are diagnosed with PCOS have difficulty conceiving, frequently requiring the use of fertility medications to induce ovulation. Unfortunately, those who do conceive experience an elevated miscarriage rate of $30-64 \%$ (compared to a rate of $12 \%$ in women with normal $\mathrm{LH}$ ) (Hamilton-Fairley and Franks, 1990; Regan et al., 1990). Because this increased miscarriage rate in women with PCOS often is attributed to poor oocyte quality (Brzyski et al., 1995), we evaluated oocyte, embryo, and maternal reproductive health in LH $\beta$ CTP transgenics (Mann et al., 1999). 
As discussed previously, oocytes from LH $\beta$ CTP transgenic mice acquire meiotic competency normally, despite early exposure to elevated LH and androgens. Subsequent studies revealed abnormalities in LH $\beta$ CTP meiotic chromosomal segregation (Hodges et al., 2002). It is possible that a pool of these oocytes would develop abnormally and result in pregnancy failure if evaluated. However, when superovulation was used to recruit a large group of oocytes, which then were fertilized and transferred to pseudopregnant, nontransgenic recipients, they developed into normal, live-born pups.

LH $\beta$ CTP females are infertile primarily because of anovulation, without ovulating spontaneously, though they will mate, as exhibited by the presence of repetitive vaginal plugs. However, both a single dose of hCG and a superovulatory regimen of pregnant mare serum gonadotropin (PMSG), followed by hCG 48 hours later, induces LH $\beta$ CTP ovulation. This suggests that chronically elevated LH causes a loss of normal LH ovulatory surges. Following superovulation and mating, $\mathrm{LH} \beta \mathrm{CTP}$ transgenics will become pregnant but they experience pregnancy failure at midgestation. By 12 days post coitus (dpc), transgenic pregnancy resorption approaches $100 \%$, whereas nontransgenic resorption reaches only $21 \%$ (elevated slightly from normal, presumably due to large litters from superovulation). The rate of pregnancy loss is plotted in Figure 6.

As discussed, embryos from transgenic females that were transferred to nontransgenic recipients developed normally to term. This result indicates that pregnancy failure in $\mathrm{LH} \beta \mathrm{CTP}$ transgenics is maternal, not embryonic, in origin. However, when embryos from nontransgenics were transferred into pseudopregnant LH $\beta$ CTP transgenics, they did not implant. This implantation failure is due to a lack of appropriate uterine receptivity, as demonstrated by the failure of transgenic uteri to undergo decidualization when stimulated with corn oil. Monitoring serum levels of progesterone throughout pseudopregnancy revealed some alterations, suggesting that the signaling pathway initiated by the mating stimulus and resulting in uterine receptivity may be abnormal in LH $\beta$ CTP females. Superovulation appears to overcome this receptivity defect and reveals a subsequent midgestation disorder.

Levels of LH, estradiol, testosterone, and progesterone were measured throughout superovulation-induced pregnancy and compared to pregnant nontransgenics. Progesterone levels were not significantly different from nontransgenics following superovulation, suggesting that corpus luteum failure was not responsible for the midgestation pregnancy resorption phenotype. Testosterone does not become elevated until $14 \mathrm{dpc}$, after the onset of pregnancy failure. Interestingly, estradiol becomes elevated 4-fold over nontransgenics from 8-14 days gestation, during the critical window of pregnancy failure. Elevated estradiol during midgestation has been shown to be toxic to embryos (Huggett and Pritchard, 1945). Elevated estradiol causes midgestation pregnancy failure in mice lacking the $5 \alpha$-reductase type I gene (Mahendroo et al., 1997). Thus, it is 


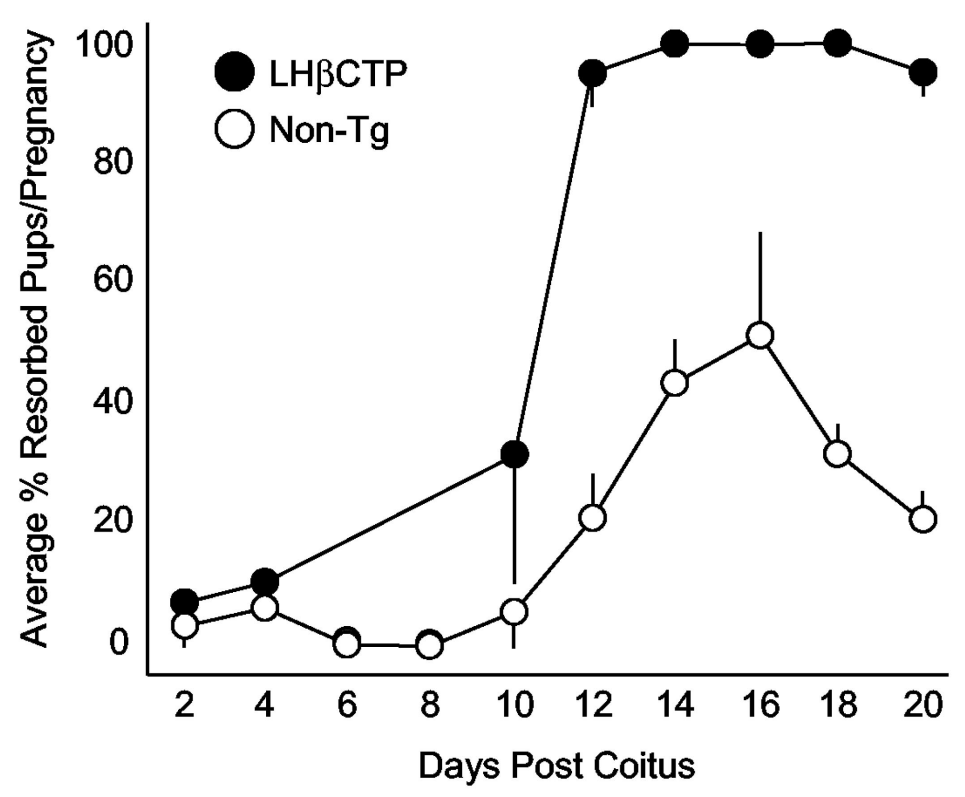

FIG. 6. Transgenic pregnancy failure begins at midgestation. Preimplantation pregnancies (2 and 4 days post coitus) were scored based upon the presence of either normally dividing embryos or dead embryos. Postimplantation pregnancies were scored based upon the presence of normal, resorbed, or dead embryos in the uterus. [Reprinted with permission from Mann RJ, Keri RA, Nilson JH 1999 Transgenic mice with chronically elevated luteinizing hormone are infertile due to anovulation, defects in uterine receptivity, and midgestation pregnancy failure. Endocrinology 140:2592-2601. Copyright The Endocrine Society.]

possible that excess estradiol is the cause of LH $\beta$ CTP midgestation pregnancy failure. Interestingly, estrogen toxicity has been used to explain some human miscarriages (Trout and Seifer, 2000). LH $\beta$ CTP pregnancy defects could be rescued, with live pups born when animals were ovariectomized following embryo transfer and treated with estrogen and progesterone during pregnancy. While inefficient, the success of this regimen demonstrated that the reproductive abnormalities experienced by LH $\beta$ CTP females are reversible (Mann et al., 1999).

This study suggests that pregnancy failure in women with elevated LH, such as those diagnosed with PCOS, may be attributed to a hostile maternal environment contributing to lack of uterine receptivity and/or pregnancy loss. Future studies to determine the molecular mechanisms involved in LH $\beta$ CTP pregnancy failure may help us to further understand the complexities behind increased miscarriage rates in women with PCOS. 


\section{ADRENAL DISTURBANCES: MODELING CUSHING'S SYNDROME}

Although most of the androgens in PCOS are secreted from the ovaries, in approximately $50 \%$ of cases, excessive production of adrenal androgens also occurs (Azziz, 1996). The underlying cause of this adrenocortical disturbance remains unclear.

The primary regulator of glucocorticoid production in the adrenal cortex is adrenocorticotropin (ACTH) (Orth and Kovacs, 1998). In humans, ACTH drives the adrenal gland to produce the glucocorticoids cortisol and corticosterone. However, corticosterone is the only glucocorticoid produced in the mouse (Spackman and Riley, 1978).

In addition to ACTH, several other hormones (e.g., LH, prolactin, insulinlike growth factor-1 (IGF-1)) have been implicated in the regulation of adrenal androgen production (Orth and Kovacs, 1998). There is some evidence that LH acts directly at the adrenal gland, although this is controversial (Parker and Odell, 1980). A case of postmenopausal Cushing's syndrome has been described in which the adrenocortical hyperfunction was found to be LH dependent and responsive to treatment with GnRH agonist (Lacroix et al., 1999). In addition, a significant proportion of women with chronic anovulation have elevated serum levels of LH and adrenal-derived androgen precursors such as dehydroepiandrosterone-sulfate (DHEA-S) but normal ACTH levels (Hoffman et al., 1984).

In Kero et al. (2000), adrenal gland function and LH receptor expression were evaluated in LH $\beta$ CTP transgenics. They presented evidence for a novel mechanism that might explain the adrenal-derived androgens in PCOS and some LH-dependent Cushing's syndrome cases.

Adrenal glands from 5-month-old transgenic females were evaluated and found to be morphologically altered, compared to nontransgenic littermates. Adrenal glands from transgenics weighed significantly more than controls $(6.0 \pm$ $0.86 \mathrm{mg}$ vs. $3.3 \pm 0.3 \mathrm{mg}$, respectively). Histological signs of cortical stimulation included increased cortical width and centripetal extension of lipid-depleted cells, widening the zona reticularis. There were also foci of acute and chronic inflammatory cells (Kero et al., 2000). Notably, lymphocyte infiltration of the adrenal gland has been observed in some patients with Cushing's syndrome (Willenberg et al., 1998).

While at 1 month of age, both transgenics and controls had a typical area of the andrenal X-zone visible, by 5 months of age, the X-zone had disappeared in transgenics. A poorly characterized area, the X-zone is thought to be involved in steroid hormone production (Hu et al., 1999). Interestingly, in normal male mice, the X-zone disappears after puberty, possibly due to testosterone (Asari et al., 1979). However, in normal females, the $X$-zone remains until after the first pregnancy (Holmes and Dickson, 1971). 
To determine whether the altered adrenal morphology reflected a change in adrenal steroidogenesis, serum corticosterone levels were measured and determined to be elevated 14-fold in female transgenics, when compared to nontransgenic controls. This elevation decreased to nearly undetectable levels following adrenalectomy, indicating that the primary source of the corticosterone was the adrenal gland. In addition, transgenic ovariectomy resulted in decreased corticosterone levels to that of nontransgenic controls. Interestingly, gonadectomy, which induces elevated LH in both males and females, did not increase corticosterone levels in nontransgenics. This suggests that the polycystic ovaries found in transgenics play a significant role in adrenal hyperfunction and that chronically elevated LH alone cannot account for the increased adrenal steroidogenesis (Kero et al., 2000).

The steroidogenic capacity of andrenal glands from 3-month-old trangenics was assessed further through culturing dispersed adrenal cells. Unstimulated cells from transgenic females produced elevated levels of cAMP, progesterone, and corticosterone, relative to nontransgenics. In addition, transgenic-derived adrenal cells responded to both hCG (in a dose-dependent manner) and ACTH treatment. However, cells from nontransgenics responded only to ACTH. These data indicate that, in addition to ACTH, an LH analog stimulates adrenal corticosterone production in transgenics. This increased steroidogenic capacity is associated with increased LH receptor expression in the transgenic adrenal gland. Significant and specific LH receptor binding in adrenal homogenates was observed in transgenic females. RT-PCR was used to demonstrate that long-term elevation of serum LH concentrations is associated with the presence of $\mathrm{LH}$ receptor mRNA in adrenal glands. LH receptor expression was observed in female transgenics by 3 months of age and in gonadectomized nontransgenics after 5 months (although at lower levels) (Kero et al., 2000). In situ hybridization localized LH receptor expression in transgenic adrenal glands across the whole cortex, including the zona glomerulosa, zona fasciculata, and zona reticularis. Thus, the presence of the cystic ovary, in conjunction with elevated LH, seems to be a requirement for achieving significant adrenal $\mathrm{LH}$ receptor expression along with functional responsiveness of adrenal cells to hCG.

Besides serving as a model for PCOS, these findings of increased corticosterone production in $\mathrm{LH} \beta \mathrm{CTP}$ transgenics suggest that these mice may provide a useful model for Cushing-like adrenocortical hyperfunction (Kero et al., 2000). Other manifestations of Cushing's syndrome (e.g., obesity) have been observed in these mice. LH $\beta$ CTP mice become obese, weighing 30\% more than their nontransgenic littermates (R.A. Keri, J. Kero, I.T. Huhtaniemi, J.H. Nilson, unpublished data). Interestingly, in rare cases of ACTH-independent Cushing's syndrome, the disease becomes more prominent during pregnancy and may improve or remit spontaneously after delivery (Da Motta et al., 1991; Buescher et al., 1992; Close et al., 1993). 
The mechanism involved in the development of this Cushing-like adrenocortical hyperfunction is unclear. It is known that LH $\beta$ CTP mice have 2- to 3 -fold elevated circulating estradiol (Risma et al., 1995). Estradiol is known to elevate prolactin, which is upregulated in transgenics by 2.5 -fold (Kero et al., 2000). Prolactin is an important regulator of LH receptor expression at both the level of transcription and translation (Huhtaniemi and Catt, 1981; Gafvels et al., 1992; Pakarinen et al., 1994). This may explain the ovarian dependence for induction of adrenal LH receptor expression and subsequent stimulation of corticosterone production by elevated LH seen in transgenics. This represents a novel mechanism behind the altered adrenocortical function observed in transgenics, which results in elevated glucocorticoid production. As these mice appear to model some aspects of both PCOS and Cushing's syndrome, further studies on adrenocortical function are warranted in humans with chronically elevated gonadotropin levels (Kero et al., 2000).

\section{E. LH ACTS AS A TUMOR PROMOTER IN LH $\beta C T P / I N H \alpha$ TAG DOUBLE TRANSGENICS}

Previous studies on mice transgenic for the inhibin- $\alpha$ promoter directing expression of the SV40 T-antigen showed that $100 \%$ of these mice developed granulosa cell or Leydig cell tumors by 5-8 months of age (Kananen et al., 1995,1996a). When gonadectomized, these mice developed adrenal gland tumors with $100 \%$ penetrance by $6-8$ months (Kananen et al., 1996b). While the adrenal tumor dependency on gonadectomy suggested a role for increased levels of gonadotropins - and, indeed, was shown to be gonadotropin dependent (Kananen et al., 1997) - these studies did not differentiate between the actions of FSH and LH. Thus, a new line of double transgenics was created to introduce the LH $\beta$ CTP transgene onto the inh $\alpha$ Tag line (Kero et al., 2002).

In the double-transgenic mice, gonadal tumorigenesis starts earlier and progresses faster, compared to inh $\alpha$ Tag transgenics. At 3 months of age, LH $\beta$ CTP female ovaries are enlarged and multicystic, while ovaries from double transgenics are even larger and present with highly proliferating tumors of granulosa cell origin. Ovaries from nontransgenics and inh $\alpha$ Tag transgenics are normal at this time point. The presence of elevated $\mathrm{LH}$ in female double transgenics enhanced the aggressiveness of their ovarian tumors. While gonadal tumors in inh $\alpha$ Tag transgenics never metastasized to other tissues, double transgenics were observed to generate metastases to the lungs and liver.

Interestingly, these studies revealed some previously unseen phenotypes in male LH $\beta$ CTP transgenics. While serum LH levels originally were not observed to be elevated in males (Risma et al., 1995), this study found slight, but significant, elevation of $\mathrm{LH}$ at $9-12$ weeks of age $(5.18 \pm 0.45 \mu \mathrm{g} / \mathrm{mL}$ vs. $1.35 \pm$ $0.34 \mu \mathrm{g} / \mathrm{mL}$ ). Additionally, some Leydig cell hyperplasia was observed. As 
previously identified, testicles from LH $\beta$ CTP males were slightly, but significantly, reduced in size (Risma et al., 1995). This can be explained by the known effects of elevated LH with concomitantly low FSH before puberty, leading to early differentiation of testicular cells and reduced testicular size (Gaytan et al., 1994). Three-month-old male double transgenics had increased testicular weight and showed massive hemorrhagic and invasive tumors originating from Leydig cells, while inh $\alpha$ Tag transgenic males showed only microscopic tumor foci at this age.

Histological signs of adrenal gland tumorigenesis in all double-transgenic females were observed in the presence of the gonad. These tumors clearly originated from the adrenal cortex. In contrast, adrenal tumors were observed in inh $\alpha$ Tag transgenics only after gonadectomy. Not surprisingly, no evidence of adrenal tumorigenesis was seen in male double transgenics, presumably due to their only slightly elevated LH levels. These findings suggest that chronically elevated $\mathrm{LH}$, in the presence of normal to decreased FSH, can act as a tumor promoter on the inh $\alpha$ Tag transgenic background.

The progression of ovarian tumorigenesis in double transgenics is associated with elevated LH receptor and inhibin- $\alpha$ gene expression. Interestingly, high serum levels of LH fail to induce downregulation of LH receptor in both $\mathrm{LH} \beta \mathrm{CTP}$ and double transgenics. Indeed, LH receptor is upregulated, indicating that the normal desensitization of LH receptor by LH is altered in these animals (Dufau, 1998). Chronic activation of the LH receptor function could act as a protooncogene, as shown with some other G protein-coupled receptors (Allen et al., 1991; Parma et al., 1993). It is possible that the enhanced tumorigenesis seen in double transgenics could be explained by LH receptor stimulation of increased cAMP production and subsequent activation of the cAMP response element (CRE) contained within the inhibin- $\alpha$ transgene promoter (Pei et al., 1991).

\section{F. MAMMARY TUMORIGENESIS: MODELING BREAST CANCER}

Mammary gland development is a hormonally regulated process. Progression of the rudimentary mammary ductal system present at birth to an extensive network following puberty and finally into a differentiated, milk-producing organ during pregnancy and lactation is mediated by estrogen, progesterone, and prolactin (Hennighausen and Robinson, 1998). These hormones also regulate the occurrence and timing of reproductive events that influence a woman's risk of developing breast cancer. While many mouse models of mammary cancer exist, few address the role that hormones play in spontaneous tumor formation.

Known risk factors for development of breast cancer include early age at menarche, late age of menopause, late age at first full-term pregnancy, or nulliparity (Kvale, 1992; Stoll et al., 1994; Armstrong et al., 2000). Interestingly, parity has a dual effect on breast cancer. While full-term pregnancy actually 
reduces long-term tumor incidence in humans and rodents (MacMahon et al., 1982; Grubbs et al, 1986), a short-term increased risk in tumor formation has been observed immediately following pregnancy (Hsieh et al., 1994; Lambe et al., 1994).

In Milliken et al. (2002), the impact of LH-mediated alterations in the hormonal milieu of LH $\beta$ CTP transgenics on the development of the mouse mammary gland was investigated. Initial studies revealed that mammary gland development is accelerated in LH $\beta$ CTP transgenics. Precocious puberty occurs in transgenics around postnatal days 21-22, at least 5 days earlier than nontransgenic littermates (Risma et al., 1997; Keri et al., 2000). To assess the impact of early ovarian activity on mammary gland morphogenesis, Milliken et al. examined glands at 3 and 5 weeks of age. By 3 weeks of age, accelerated development of the mammary gland was observed in transgenic mice (Figures 7A and B). This accelerated growth of the transgenic mammary gland was more apparent by 5 weeks of age (Figures 7C and D). While the ductal network in nontransgenics progressed through only half of the mammary gland fat pad by 5 weeks of age,
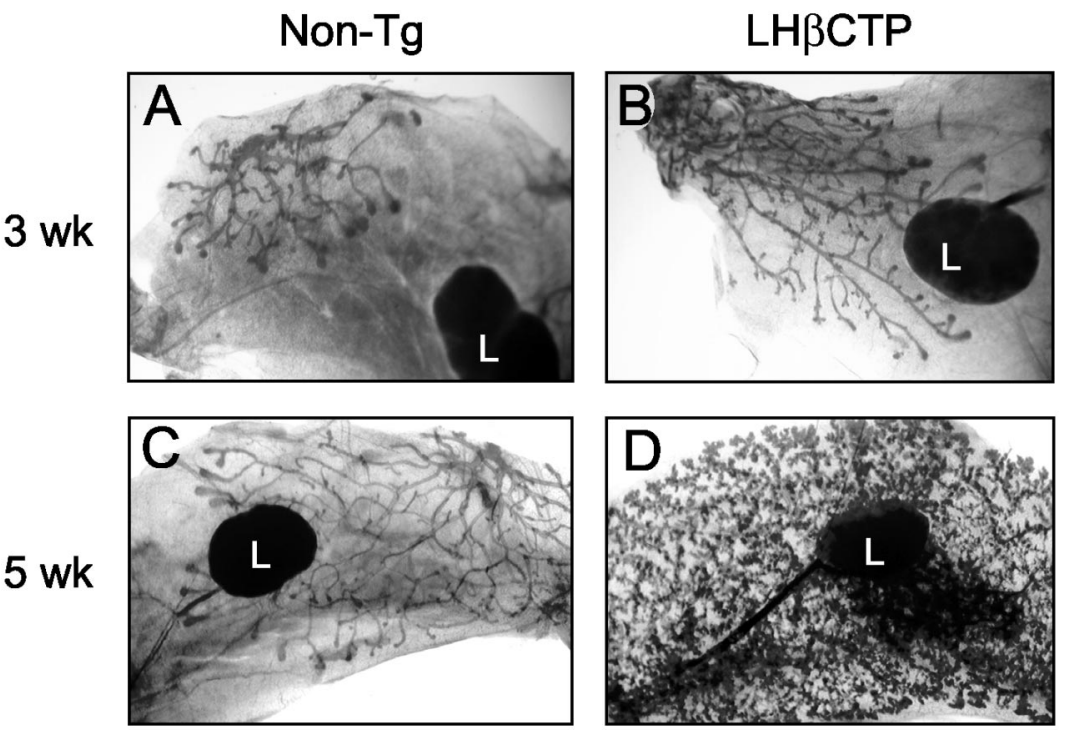

FIG. 7. Mammary gland development is accelerated in LH $\beta$ CTP mice. Whole mounts of inguinal mammary glands (\#4) were prepared from nontransgenic (A and C) or LH $\beta$ CTP (B and D) mice that were either $3(\mathrm{~A}$ and $\mathrm{B})$ or $5(\mathrm{C}$ and $\mathrm{D})$ weeks of age. "L" indicates the mammary gland-associated lymph node. [Reprinted with permission from Milliken EL, Ameduri RK, Landis MD, Behrooz A, Abdul-Karim FW, Keri RA 2002 Ovarian hyperstimulation by luteinizing hormone leads to mammary gland hyperplasia and cancer predisposition in transgenic mice. Endocrinology 143:3671-3680. Copyright The Endocrine Society.] 
the entire fat pad of the transgenic mouse was filled with ducts that displayed abundant alveoli and a loss of terminal end buds (Milliken et al., 2002). This pattern of development closely resembles that seen at mid- to late pregnancy in normal mice (Hennighausen and Robinson, 1998).

Further histological examination of adult transgenic mammary glands revealed extensive epithelial hyperplasia with considerable alveolar development and accumulation of lipid droplets. This hyperplasia was determined to be due to a 12-fold increase in proliferation, as measured by incorporation of bromodeoxyuridine (BrdU). However, a corresponding change in the rate of apoptosis in these glands was not observed. The histological evidence of pregnancy-like morphology was supported by the expression pattern of molecular markers of pregnancy-induced differentiation within mammary glands of transgenics. Milk protein genes, whey acidic protein (WAP), $\beta$-casein, and Westmead DMBA-8 nonmetastatic cDNA 1 (WDNM1) expression levels in transgenics corresponded to those observed in nontransgenics at day 14 of pregnancy. These findings suggest that mammary glands from virgin transgenic animals exposed to excessive LH develop a phenotype that simulates midpregnancy (Milliken et al., 2002).

Ovariectomy was performed to determine whether the mammary hyperplasia observed in transgenics was due to direct action of LH or whether it required LH-induced ovarian hyperstimulation. Mammary glands collected after 21 days postovariectomy showed complete regression of the gland, compared to sham surgery controls. These results indicate that hyperplasia is reversible and requires ovary-derived factors.

While transgenics develop spontaneous mammary tumors (mostly mammary intraepithelial neoplasias (MINs)) with 50\% penetrance by 41 weeks (Figure 8), treatment with the mammary carcinogen, 7,12-dimethylbenz(a)anthracene (DMBA) accelerates tumor formation. Transgenics treated with DMBA develop invasive mammary carcinomas with squamous metaplasia beginning at 13.5 weeks posttreatment (with $100 \%$ penetrance by 20 weeks), while only $20 \%$ of nontransgenic controls treated with DMBA developed tumors by 56 weeks postexposure. These data demonstrate that $\mathrm{LH} \beta \mathrm{CTP}$ transgenics are predisposed to mammary carcinogenesis, when compared to their nontransgenic littermates.

Levels of estrogen, progesterone, and prolactin in transgenics were measured at several different ages (starting at 5 weeks), to identify the hormonal profile that supports the development of mammary hyperplasia and subsequent tumor development. Significant increases in estrogen and progesterone were detected in transgenics at 5 weeks of age, while prolactin became significantly elevated later in life, perhaps due to chronic elevations in estrogen, which increases lactotrope secretion of prolactin (Ascoli and Segaloff, 1996). Tumor-bearing mice have significantly higher levels of both estrogen and prolactin, while progesterone remains comparable to levels seen at nontumor-bearing transgenics at 20 weeks. 


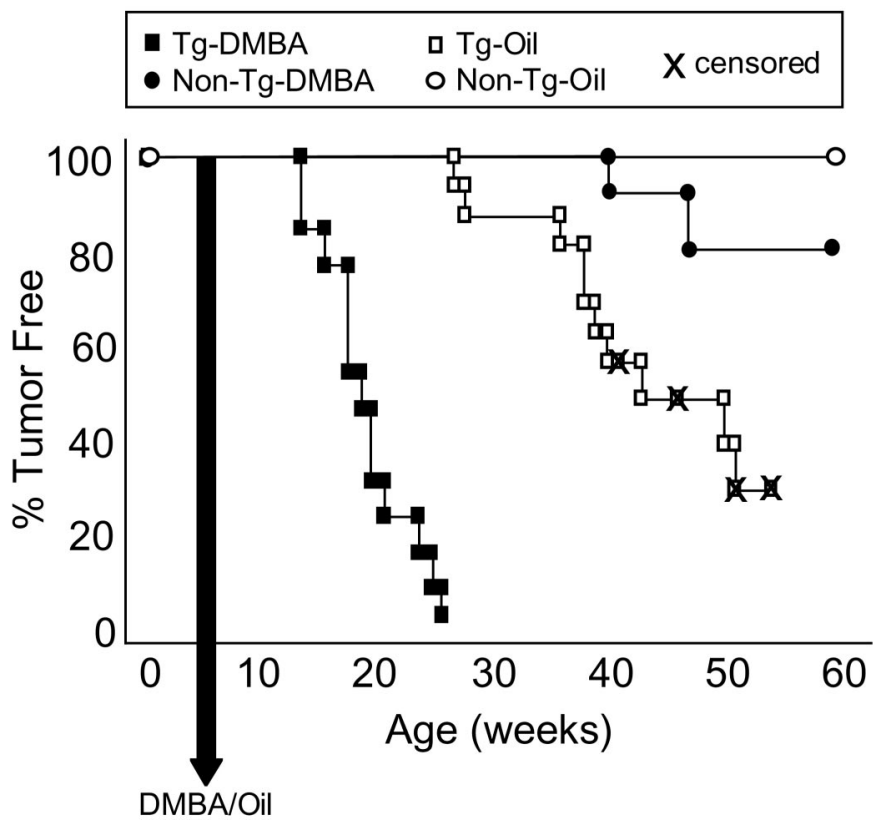

FIG. 8. LH $\beta$ CTP transgenic mice are predisposed to mammary cancer. Transgenic and nontransgenic female littermates were treated with either dimethylbena(a)anthracene (DMBA) or corn oil at 5 and 6 weeks of age (indicated by gray arrow). Censored events (i.e., removal of an animal from the experiment because of death or sickness) are marked with an "X." Spontaneous tumor latency in transgenic mice was found to be 41 weeks using Kaplan-Meier survival analysis. [Reprinted with permission from Milliken EL, Ameduri RK, Landis MD, Behrooz A, Abdul-Karim FW, Keri RA 2002 Ovarian hyperstimulation by luteinizing hormone leads to mammary gland hyperplasia and cancer predisposition in transgenic mice. Endocrinology 143:3671-3680. Copyright The Endocrine Society.]

It is known that growth of mammary tumors can be classified as either hormone dependent or independent. Analysis of human breast tumors has revealed a significant correlation between expression of estrogen and progesterone receptors and hormone growth dependency (DePlacido et al., 1990; Ormandy et al., 1997). Immunohistochemical analysis of the spontaneous mammary tumors formed in transgenics for progesterone receptor (PR) indicated that while normal tissue adjacent to tumor cells did express nuclear PR, tumor cells did not. Unfortunately, detection of estrogen receptor (ER) expression was not possible at that time.

These studies have demonstrated that chronic exposure to elevated LH leads to precocious mammary gland development and ovary-dependent mammary hyperplasia. Hyperplasia is due to an increase in epithelial cell proliferation. It 
will be important to determine whether precocious puberty in LH $\beta$ CTP transgenics significantly contributes to their development of mammary tumors, considering that early puberty is a risk factor for breast cancer in humans (Apter et al., 1989).

Despite histological and molecular markers suggesting the mammary glands are in a midpregnancy-like state, LH $\beta$ CTP transgenics have accelerated tumor formation. This finding contrasts with studies indicating a protective effect of pregnancy against mammary tumor formation. The apparent discrepancy may suggest that the protection achieved through pregnancy is regulated by the extent and timing of hormone elevation.

Further studies are being performed to dissect the molecular mechanisms that govern the hormone-induced mammary tumorigenesis seen in this model. Gene-expression profiling has revealed many genes that behave similarly in transgenic and pregnant mammary glands, as compared to virgin nontransgenics. However, there are also many genes that behave differentially between the transgenic and pregnant glands. Understanding these similarities and differences may reveal novel mechanisms by which to develop therapies to treat and prevent human breast cancer.

\section{Conclusions}

LH hypersecretion in LH $\beta$ CTP transgenic mice leads to the development of a diverse spectrum of physiological pathologies. Modeling ovarian tumorigenesis, granulosa cell tumors, which are strain dependent, develop in transgenics by 5 months of age and are preventable when animals are exposed to regular hCG surges. Modeling perimenopausal reproductive aging and POF, primordial follicles are depleted by $45 \%$ in LH $\beta$ CTP transgenics at 5 weeks of age. While oocyte meiotic competency is acquired normally, elevated LH increases the rate of meiotic segregation defects, which contributes to nondisjunction-related aneuploidy in females. Modeling infertility and PCOS, transgenics are infertile due to anovulation and undergo pregnancy failure at midgestation following superovulation. Transgenics exhibit a lack of uterine receptivity, despite the induction of pseudopregnancy through mating. Modeling Cushing's syndrome, adrenal glands from transgenics exhibit adrenocortical hyperfunction, with increased production of corticosterone following induction of LH receptor in response to elevated circulating LH. Modeling breast cancer, chronic exposure to elevated LH leads to mammary gland tumorigenesis.

The diversity of physiological systems ultimately impacted by LH hypersecretion is revealed through the LH $\beta$ CTP transgenic mouse model. Future studies investigating the downstream signaling pathways and molecular mechanisms involved in the generation of these LH-induced pathologies should support the 
notion that the LH $\beta$ CTP transgenic mouse model may be a useful resource for both transcriptome and proteome profiling.

\section{ACKNOWLEDGMENTS}

We would like to thank Dr. Christine Quirk and Tehnaz Parakh for their advice and help. We also acknowledge support from the National Institutes of Health, grant CA 086387 (J.H.N.), and the Department of Defense, grant DAMD 17-01-1-0195 (R.A.K.).

\section{REFERENCES}

Abbud RA, Ameduri RK, Rao JS, Nett TM, Nilson JH 1999 Chronic hypersecretion of luteinizing hormone in transgenic mice selectively alters responsiveness of the $\alpha$-subunit gene to gonadotropin-releasing hormone and estrogens. Mol Endocrinology 13:1449-1459

Adams J, Polson DW, Franks S 1986 Prevalence of polycystic ovaries in women with anovulation and idiopathic hirsutism. Br Med J 293:355-359

Allen LF, Lefkowitz RJ, Caron MG, Cotecchia S 1991 G-protein-coupled receptor genes as protooncogenes: constitutively activating mutation of the alpha 1B-adrenergic receptor enhances mitogenesis and tumorigenicity. Proc Natl Acad Sci USA 88:11354-11358

Amsterdam A, Selvaraj N 1997 Control of differentiation, transformation, and apoptosis in granulosa cells by oncogenes, oncoviruses, and tumor suppressor genes. Endocr Rev 18:435461

Andriole VT 1975 Urinary tract infections in pregnancy. Urol Clin N Am 2:485-498

Apter D, Reinila M, Vihko R 1989 Some endocrine characteristics of early menarche, a risk factor for breast cancer, are preserved into adulthood. Int J Cancer 44:783-787

Armstrong K, Eisen A, Weber B 2000 Assessing the risk of breast cancer. N Engl J Med 342:564-571

Asari M, Fukaya K, Eguchi Y, Nishida S, Kano Y 1979 Effect of testosterone and progesterone on the adrenal X-zone in female mice. Nippon Juigaku Zasshi 41:61-67

Ascoli M, Segaloff DL 1996 Adenohypophyseal hormones and their hypothalamic releasing factor. In: Hardman JG, Limbard LE, eds. Goodman \& Gilman's The Pharmacological Basis of Therapeutics. New York: McGraw-Hill; 1363-1382

Ascoli M, Fanelli F, Segaloff DL 2002 The lutropin/choriogonadotropin receptor, a 2002 perspective. Endocr Rev 23:141-174

Azziz R 1996 The adrenal connection. In: Adashi E, Rock J, Rosenwaks Z, eds. Reproductive Endocrinology, Surgery, and Technology, vol 1. Philadelphia: Lippincott-Raven Publishers; $1161-1180$

Balen AH, Tan SL, Jacobs HS 1993 Hypersecretion of luteinizing hormone: a significant cause of infertility and miscarriage. Br J Obstet Gynecol 100:1082-1089

Battaglia DE, Goodwin P, Klein NA 1996 Influence of maternal age on meiotic spindle assembly in oocytes from naturally cycling women. Hum Reprod 11:2217-2222

Bione S, Sala C, Manzini C, Arrigo G, Zuffardi O, Banfi S, Borsani G, Jonveaux P, Philippe C, Zuccotti M, Ballabio A, Toniolo D 1998 A human homologue of the Drosophila melanogaster diaphanous gene is disrupted in a patient with premature ovarian failure: evidence for conserved function in oogenesis and implications for human sterility. Am J Hum Genet 62:533-541

Bousfield GR, Perry WM, Ward DN 1994 Gonadotropins chemistry and biosynthesis. In: Knobil E, Neill JD, eds. The Physiology of Reproduction, edit 2. New York: Raven Press, Ltd; $1749-1791$ 
Brzyski RG, Grow DR, Sims JA, Seltman HJ 1995 Increase in androgen:estrogen ratio specifically during low-dose follicle-stimulating hormone therapy for polycystic ovary syndrome. Fertil Steril 64:693-697

Buescher MA, McClamrock HD, Adashi EY 1992 Cushing syndrome in pregnancy. Obstet Gynecol 79:130-137

Burke DJ 2000 Complexity in the spindle checkpoint. Curr Opin Genet Dev 10:26-31

Cho RJ, Campbell MJ, Winzeler EA, Steinmetz L, Conway A, Wodicka L, Wolfsberg TG, Gabrielian AE, Landsman D, Lockhart DJ, Davis RW 1998 A genome-wide transcriptional analysis of the mitotic cell cycle. Mol Cell 2:65-73

Clay CM, Keri RA, Finicle AB, Heckert LL, Hamernik DL, Marschke KM, Wilson EM, French FS, Nilson JH 1993 Transcriptional repression of the glycoprotein hormone $\alpha$ subunit gene by androgen may involve direct binding of androgen receptor to the proximal promoter. J Biol Chem 268:13556-13564

Close CF, Mann MC, Watts JF, Taylor KG 1993 ACTH-independent Cushing's syndrome in pregnancy with spontaneous resolution after delivery: control of the hypercortisolism with metyrapone. Clin Endocrinol (Oxf) 39:375-379

Cohen I, Speroff L 1991 Premature ovarian failure: update. Ob-Gyn Surv 46:156-162

Corriere JN Jr, Murphy JJ 1968 The effect of oestrogen upon ascending urinary tract infection in rats. Br J Urol 40:306-314

Da Motta LA, Motta LD, Barbosa AM, Ferreira MA, Gagliardi AR 1991 Two pregnancies in a Cushing's syndrome. Case report. Panminerva Med 33:44-47

deKretser DM, Meinhardt A, Meehan T, Phillips DJ, O'Bryan MK, Loveland KA 2000 The roles of inhibin and related peptides in gonadal function. Mol Cell Endocrinol 161:43-46

DePlacido S, Gallo C, Perrone F, Marinelli A, Pagliarulo C, Carlomagno C, Petrella G, D'Istria M, Delrio G, Bianco AR 1990 Prolactin receptor does not correlate with oestrogen and progesterone receptors in primary breast cancer and lacks prognostic significance. Br J Cancer 62:643-646

de Roux N, Milgrom E 2001 Inherited disorders of GnRH and gonadotropin receptors. Mol Cell Endocrinol 179:83-87

Dufau ML 1998 The luteinizing hormone receptor. Annu Rev Physiol 60:461-496

Faddy MJ, Gosden RG, Gougeon A, Richardson SJ, Nelson JF 1992 Accelerated disappearance of ovarian follicles in mid-life: implications for forecasting menopause. Hum Reprod 7:1342-1346

Flaws JA, Abbud R, Mann RJ, Nilson JH, Hirshfield AN 1997 Chronically elevated luteinizing hormone depletes primordial follicles in the mouse ovary. Biol Reprod 57:1233-1237

Fontanelli R, Stefanon B, Raspagliesi F, Kenda R, Tomasic G, Spatti G, Riboldi G, DiDonato P, Pilotti S, DePalo G 1998 Adult granulosa cell tumor of the ovary: a clinico pathologic study of 35 cases. Tumori 84:60-64

Franks S 1995 Polycystic ovary syndrome. N Engl J Med 33:853-861

Gafvels M, Bjurulf E, Selstam G 1992 Prolactin stimulates the expression of luteinizing hormone/ chorionic gonadotropin receptor messenger ribonucleic acid in the rat corpus luteum and rescues early pregnancy from bromocriptine-induced abortion. Biol Reprod 47:534-540

Gajewska A, Kochman K 2001 GnRH pulsality and the differential activation of the rat luteinizing hormone subunit genes in the anterior pituitary gland. Neuroendocrinol Lett 22:435-440

Gaytan F, Pinilla L, Romero JL, Aguilar E 1994 Differential effects of the administration of human chorionic gonadotropin to postnatal rats. J Endocrinol 142:527-534

Gercel-Taylor C, Taylor DD 1996 Effect of patient-derived lipids on in vitro expression of oncogenes by ovarian tumor cells. Gynecol Obstet Invest 42:42-48

Gore-Langton RE, Armstrong DT 1994 Follicular steroidogenesis and its control. In: Knobil E, Neill JD, eds. The Physiology of Reproduction, edit 2. New York: Raven Press; 571-627 
Grubbs CJ, Juliana MM, Hill DL, Whitaker LM 1986 Suppression by pregnancy of chemically induced preneoplastic cells of the rat mammary gland. Anticancer Res 6:1395-1400

Haisenleder DJ, Dalkin AC, Marshall JC 1994 Regulation of gonadotropin gene expression. In: Knobil E, Neill JD, eds. The Physiology of Reproduction, edit 2. New York: Raven Press; 1793-1813

Hamernik DL, Keri RA, Clay CM, Clay JN, Sherman GB, Sawyer HR, Nett TM, Nilson JH 1992 Gonadotrope- and thyrotrope-specific expression of the human and bovine glycoprotein hormone $\alpha$-subunit genes is regulated by distinct cis-acting elements. Mol Endocrinol 6:1745-1755

Hamilton-Fairley D, Franks S 1990 Common problems in induction of ovulation. Bailliere's Clin Obstet Gynaecol 4:609-625

Hassold T, Chiu D 1985 Maternal age specific rates of numerical chromosome abnormalities with special reference to trisomy. Hum Genet 70:11-17

Hassold T, Hunt PA 2001 To err (meiotically) is human: the genesis of human aneuploidy. Nat Rev Genet 2:280-291

Hennighausen L, Robinson GW 1998 Think globally, act locally: the making of a mouse mammary gland. Genes Dev 12:449-455

Hodges CA, Ilagan A, Jennings D, Keri R, Nilson J, Hunt PA 2002 Experimental evidence that changes in oocyte growth influence meiotic chromosome segregation. Hum Reprod 17:11711180

Hoffman DI, Klove K, Lobo RA 1984 The prevalence and significance of elevated dehydroepiandrosterone sulfate levels in anovulatory women. Fertil Steril 42:76-81

Holmes PV, Dickson AD 1971 X-zone degeneration in the adrenal glands of adult and immature female mice. J Anat 108:159-168

Hsieh C, Pavia M, Lambe M, Lan SJ, Colditz GA, Ekbom A, Adami HO, Trichopoulos D, Willett WC 1994 Dual effect of parity on breast cancer risk. Eur J Cancer 30A:969-973

Hsueh AJ, Billig H, Tsafriri A 1994 Ovarian follicle atresia: a hormonally controlled apoptotic process. Endocr Rev 15:707-724

Hu M, Chou S, Huang Y, Hsu N, Hung L, Chung B 1999 Tissue-specific, hormonal, and developmental regulation of SCC-LacZ expression in transgenic mice leads to adrenocortical zone characterization. Endocrinology 140:5609-5618

Huggett ASG, Pritchard JJ 1945 Experimental foetal death: the surviving placenta. Proc Royal Soc Med 38:261-266

Huhtaniemi IT, Catt KJ 1981 Induction and maintenance of gonadotropin and lactogen receptors in hypoprolactinemic rats. Endocrinology 109:483-490

Jacobs HS, Homburg RR 1990 The endocrinology of conception. Bailliere's Clin Endocrinol Metab 4:195-205

Kananen K, Markkula M, Rainio E, Su JG, Hsueh AJ, Huhtaniemi IT 1995 Gonadal tumorigenesis in transgenic mice bearing the mouse inhibin alpha-subunit promoter/simian virus T-antigen fusion gene: characterization of ovarian tumors and establishment of gonadotropinresponsive granulosa cell lines. Mol Endocrinol 9:616-627

Kananen K, Markkula M, el-Hefnawy T, Zhang FP, Paukku T, Su JG, Hsueh AJ, Huhtaniemi I 1996a The mouse inhibin alpha-subunit promoter directs SV40 T-antigen to Leydig cells in transgenic mice. Mol Cell Endocrinol 119:135-146

Kananen K, Markkula M, Mikola M, Rainio EM, McNeilly A, Huhtaniemi I 1996b Gonadectomy permits adrenocortical tumorigenesis in mice transgenic for the mouse inhibin alphasubunit promoter/simian virus 40 T-antigen fusion gene: evidence for negative autoregulation of the inhibin alpha-subunit gene. Mol Endocrinol 10:1667-1677

Kananen K, Rilianawati K, Paukku T, Markkula M, Rainio EM, Huhtanemi I 1997 Suppression of gonadotropins inhibits gonadal tumorigenesis in mice transgenic for the mouse inhibin 
alpha-subunit promoter/simian virus 40 T-antigen fusion gene. Endocrinology 138:35213531

Kendall SK, Saunders TL, Jin L, Lloyd RV, Glode LM, Nett TM, Keri RA, Nilson JH, Camper SA 1991 Targeted ablation of pituitary gonadotropes in transgenic mice. Mol Endocrinol 5:2025-2036

Keri RA, Andersen B, Kennedy GC, Hamernik DL, Clay CM, Brace AD, Nett TM, Notides AC, Nilson JH 1991 Estradiol inhibits transcription of the human glycoprotein hormone $\alpha$-subunit gene despite the absence of a high affinity binding site for estrogen receptor. Mol Endocrinol 5:725-733

Keri RA, Lozada KL, Abdul-Karim FW, Nadeau JH, Nilson, JH 2000 Luteinizing hormone induction of ovarian tumors: oligogenic differences between mouse strains dictates tumor disposition. Proc Natl Acad Sci USA 97:383-387

Kero J, Poutanen M, Zhang F, Rahman N, McNicol AM, Nilson JH, Keri RA, Huhtaniemi IT 2000 Elevated luteinizing hormone induces expression of its receptor and promotes steroidogenesis in the adrenal cortex. J Clin Invest 105:633-641

Kero J, Mikola M, Nilson JH, Keri RA, Poutanen M, Huhtaniemi I 2002 High levels of luteinizing hormone stimulate gonadal and adrenal tumorigenesis in mice transgenic for the mouse inhibin $\alpha$-subunit promoter/Simian virus $40 \mathrm{~T}$-antigen fusion gene. Oncogene, in press

Kraus S, Naor Z, Seger R 2001 Intracellular signaling pathways mediated by the gonadotropinreleasing hormone $(\mathrm{GnRH})$ receptor. Arch Med Res 32: 499-509

Kumar TR, Wang Y, Matzuk MM 1996 Gonadotropins are essential modifier factors for gonadal tumor development in inhibin-deficient mice. Endocrinology 137:4210-4216

Kumar TR, Palapattu G, Wang P, Woodruff TK, Boime I, Byrne MC, Matzuk MM 1999 Transgenic models to study gonadotropin function: the role of follicle-stimulating hormone in gonadal growth and tumorigenesis. Mol Endocrinol 13:851-865

Kvale G 1992 Reproductive factors in breast cancer epidemiology. Acta Oncol 31:187-194

Lacroix A, Hamet P, Boutin JM 1999 Leuprolide acetate therapy in luteinizing hormone-dependent Cushing's syndrome. N Engl J Med 341:1577-1581

Lambe M, Hsieh C, Trichopoulos D, Ekbom A, Pavia M, Adami HO 1994 Transient increase in the risk of breast cancer after giving birth. N Engl J Med 331:5-9

Lee WL, Yuan CC, Lai CR, Wang PH 1999 Hemoperitoneum is an initial presentation of recurrent granulosa cell tumors of the ovary. Jpn J Clin Oncol 29:509-512

Legro RS, Spielman R, Urbanek M, Driscoll D, Strauss JF, Dunaif A 1998 Phenotype and genotype in polycystic ovary syndrome. Recent Prog Horm Res 53:217-256

LeMaire-Adkins R, Radke K, Hunt PA 1997 Lack of checkpoint control at the metaphaseanaphase transition: a mechanism of meiotic non-disjunction in mammalian females. J Cell Biol 139:1611-1619

Luthra K, Chapekar TN 1998 Oncogene expression as detected by immunocytochemical staining in hormonally induced ovarian cell lines. Indian J Exp Biol 35:447-455

MacMahon B, Purde M, Cramer D, Hint E 1982 Association of breast cancer risk with age at first and subsequent births: a study in the population of the Estonian Republic. J Natl Cancer Inst 69:1035-1038

Mahendroo MS, Cala KM, Landrum CP, Russell DW 1997 Fetal death in mice lacking $5 \alpha$-reductase type I caused by estrogen excess. Mol Endocrinol 11:917-927

Mann RJ, Keri RA, Nilson JH 1999 Transgenic mice with chronically elevated luteinizing hormone are infertile due to anovulation, defects in uterine receptivity, and midgestation pregnancy failure. Endocrinology 140:2592-2601

Marcus M, Gunfeld L, Berkowitz G, Kaplan P, Godbold J 1993 Urinary follicle-stimulating hormone as a biological marker of ovarian toxicity. Fertil Steril 59:931-933 
Mathews DM, Andrews WW, Parker R Jr, Ojeda SR 1987 A role for aromatizable androgens in female rat puberty. Biol Reprod 36:836-843

Matzuk MM, Finegold MJ, Su JG, Hsueh AJ, Bradley A 1992 Alpha-inhibin is a tumoursuppressor gene with gonadal specificity in mice. Nature 360:313-319

Milliken EL, Ameduri RK, Landis MD, Behrooz A, Abdul-Karim FW, Keri RA 2002 Ovarian hyperstimulation by luteinizing hormone leads to mammary gland hyperplasia and cancer predisposition in transgenic mice. Endocrinology 143:3671-3680

Nilson JH, Abbud RA, Keri RA, Quirk CC 2000 Chronic hypersecretion of luteinizing hormone in transgenic mice disrupts both ovarian and pituitary function, with some effects modified by the genetic background. Rec Progr Horm Res 55:69-91

Ormandy CJ, Hall RE, Manning DL, Robertson JF, Blamey RW, Kelly PA, Nicholson RI, Sutherland RL 1997 Coexpression and cross-regulation of the prolactin receptor and sex steroid hormone receptors in breast cancer. J Clin Endocrinol Metab 82:3692-3699

Orth DN, Kovacs W 1998 The adrenal cortex. In: Wilson JD, Foster DW, Kronenberg HM, Larsen PR, eds. Williams Textbook of Endocrinology. Philadelphia: WB Saunders Co; 517-664

Owens GE, Keri RA, Nilson JH 2002 Ovulatory surges of hCG prevent hormone-induced granulosa cell tumor formation leading to the identification of tumor-associated changes in the transcriptome. Mol Endocrinol 16:1230-1242

Page RB 1994 The anatomy of the hypothalamo-hypophysial complex. In: Knobil E, Neill JD, eds. The Physiology of Reproduction, edit 2. New York: Raven Press; 1527-1619

Pakarinen P, Niemimaa T, Huhtaniemi IT, Warren DW 1994 Transcriptional and translational regulation of $\mathrm{LH}$, prolactin and their testicular receptors by hCG and bromocriptine treatments in adult and neonatal rats. Mol Cell Endocrinol 101:37-47

Parma J, Duprez L, Van Sande J, Cochaux P, Gervy C, Mockel J, Dumont J, Vassart G 1993 Somatic mutations in the thyrotropin receptor gene cause hyperfunctioning thyroid adenomas. Nature 365:649-651

Parker LN, Odell WD 1980 Control of adrenal androgen secretion. Endocr Rev 1:392-410

Pei L, Dodson R, Schoderbek W, Maurer R, Mayo K 1991 Regulation of the alpha inhibin gene by cyclic adenosine $3^{\prime}, 5^{\prime}$-monophosphate after transfection into rat granulosa cells. Mol Endocrinol 5:521-534

Piana S, Nogales FF, Corrado S, Cardinale L, Gusolfino D, Rivasi F 1999 Pregnancy luteoma with granulosa cell proliferation: an unusual hyperplastic lesion arising in pregnancy and mimicking an ovarian neoplasia. Pathol Res Pract 195:859-863

Rebar RW 1982 Hypergonadotropic amenorrhea and premature ovarian failure: a review. J Reprod Med 27:179-186

Regan L, Owen EJ, Jacobs HS 1990 Hypersecretion of luteinising hormone, infertility and miscarriage. Lancet 336:1141-1144

Richardson SJ, Nelson JF 1990 Follicular depletion during the menopausal transition. Ann NY Acad Sci 592:13-20

Richardson SJ, Senikas V, Nelson JF 1987 Follicular depletion during the menopausal transition: evidence for accelerated loss and ultimate exhaustion. J Clin Endocrinol Metab 65:1231-1237

Risma KA, Clay CM, Nett TM, Wagner T, Yun J, Nilson JH 1995 Targeted overexpression of luteinizing hormone in transgenic mice leads to infertility, polycystic ovaries, and ovarian tumors. Proc Natl Acad Sci USA 92:1322-1326

Risma KA, Hirshfield AN, Nilson JH 1997 Elevated luteinizing hormone in prepubertal transgenic mice causes hyperandrogenemia, precocious puberty, and substantial ovarian pathology. Endocrinology 138:3540-3547

Russell P 1997 The clinicopathological features of primary ovarian failure. Verh Dtsch Ges Pathol 81:197-209 
Shah JV, Cleveland DW 2000 Waiting for anaphase: Mad2 and the spindle assembly checkpoint. Cell 103:997-1000

Sharpe, R 1994 Regulation of spermatogenesis. In: Knobil E, Neill JD, eds. The Physiology of Reproduction, edit 2. New York: Raven Press; 1363-1434

Sherman BM, West JH, Korenman SG 1976 The menopausal transition: analysis of LH, FSH, estradiol, and progesterone concentrations during menstrual cycles of older women. J Clin Endocrinol Metab 42:629-636

Shoham Z, Jacobs HS, Insler V 1993 Luteinizing hormone: its role, mechanism of action, and detrimental effects when hypersecreted during the follicular phase. Fertil Steril 59:1153-1161

Simerly C, Balczon R, Brinkley B, Shatten G 1990 Microinjected kinetochore antibodies interfere with chromosome movement in meiotic and mitotic mouse oocytes. J Cell Biol 111:14911504

Spackman DH, Riley V 1978 Corticosterone concentrations in the mouse. Science 200:87

Stoll BA, Vatten LJ, Kvinnsland S 1994 Does early physical maturity influence breast cancer risk? Acta Oncol 33:171-176

Tamayo P, Slonim D, Mesirov J, Zhu Q, Kitareewan S, Dmitrovsky E, Lander ES, Golub TR 1999 Interpreting patterns of gene expression with self-organizing maps: methods and application to hematopoietic differentiation. Proc Natl Acad Sci USA 96:2907-2912

Trout SW, Seifer DB 2000 Do women with unexplained recurrent pregnancy loss have higher day 3 serum FSH and estradiol values? Fertil Steril 74:335-337

Versnel MA, Haarbrink M, Langerak AW, de Laat PA, Hagemeijer A, van der Kwast TH, Berg-Bakker LA, Schrier PI 1994 Human ovarian tumors of epithelial origin express PDGF in vitro and in vivo. Cancer Genet Cytogenet 73:60-64

Volarcik K, Sheean L, Goldfarb J, Woods L, Abdul-Karim F, Hunt PA 1998 The meiotic competence of in vitro matured human oocytes is influenced by donor age: evidence that folliculogenesis is compromised in the reproductively age ovary. Hum Reprod 13:154-160

Wasserman PM, Albertini DF 1994 The mammalian ovum. In: Knobil E, Neill JD, eds. The Physiology of Reproduction, edit 2. New York: Raven Press; 79-121

Willenberg HS, Stratakis CA, Marx C, Ehrhart-Bornstein M, Chrousos GP, Bornstein SR 1998 Aberrant interleukin-1 receptors in a cortisol-secreting adrenal adenoma causing Cushing's syndrome. N Engl J Med 339:27-31

Wood KW, Sakowicz R, Goldstein LSB, Cleveland DW 1997 CENP-E is a plus end-directed kinetochore motor required for metaphase chromosome alignment. Cell 91:357-366

Woods LM, Hodges C, Baart E, Baker SM, Liskay M, Hunt PA 1999 Chromosomal control of meiotic spindle assembly: abnormal meiosis in female Mlh1 mutant mice. J Cell Biol 145:1395-1406

Wynder EL, Dodo H, Barber HR 1969 Epidemiology of cancer of the ovary. Cancer 23:352-370 